\title{
Natural Scientific Analyses at the Archaeological Excavations in Budmerice: Methods, Results, and Perspectives
}

\author{
Pavol Jelínek ${ }^{\mathrm{a}^{*}}$, Jana Hlavatáa , Július Vavák ${ }^{\mathrm{b}}$, Radoslav Beňušc, Eva Jamrichovád,e \\ ${ }^{a}$ Slovak archeological and historical institute - SAHI, Vajnorská 8/A, 83104 Bratislava, Slovakia \\ ${ }^{b}$ Small Carpathian Museum in Pezinok, Milana Rastislava Štefánika, 90201 Pezinok, Slovakia \\ 'Department of Anthropology, Comenius University, Mlynská dolina B2, 84215 Bratislava, Slovakia \\ ${ }^{d}$ Department of Ecology, Institute of Botany, Academy of Sciences of the Czech Republic, 60300 Brno, Czech Republic \\ ${ }^{e}$ Department of Botany, Faculty of Sciences, Charles University, 12801 Praha 2, Czech Republic
}

\section{ARTICLE INFO}

\section{Article history:}

Received: 27. February 2013

Accepted: 9. July 2013

\section{Key words:}

Early Bronze Age

Mad'arovce culture

anthropology

archaeobotany

palynology

storage pits

\begin{abstract}
A BSTRACT
The article presents the employment of several natural scientific methods which were used at the systematic excavations of a Mad'arovce culture fortified settlement from the Early Bronze Age in Budmerice. The paper is focused on site description, excavation methods and both the used and planned interdisciplinary methods for processing the archaeological data and finds. The aim of the excavations was to collect new data and present new results which will contribute to research on Mad'arovce culture which is currently a subject of increased attention.
\end{abstract}

\section{Introduction}

The excavations of the fortified settlements of Mad'arovce culture have been carried out for more than 100 years. They have actually been realised in each decade. The excavation results were, unfortunately, often only published in the form of preliminary reports without a thorough evaluation, or in better cases only published partially or in the form of material catalogues. This trend has improved over the last decade, however, primarily thanks to academic studies focused on processing of archaeological material from older excavations (e.g. Vavák 2004), or on theoretical research (e.g. Vavák 2007; Schvarcová 2009). These works are often remaining unpublished.

Apart from modest theoretical research, up until now stagnating field research has been developing once again. At the present time, revisory as well as systematic excavations are being carried out (Rybník, Santovka, Vráble).

"Corresponding author. E-mail: pavol.jelinek@gmail.com
As of 2010, the Slovak archaeological and historical institute (SAHI, civil association) in Bratislava, and The Small Carpathians Museum in Pezinok (Malokarpatské múzeum v Pezinku) have been conducting systematic excavations of the fortified settlement in Budmerice, district Pezinok (Figure 1).

The aim of our excavations is to carry out as much thorough research as possible. The results obtained should be used for the extensive reconstruction of previous reality. This should begin with the biotope and move on to the economic background and economic activities to the social structure and expression of the spiritual life of the former inhabitants, as this will be made possible by the employed methods. It is therefore necessary to systematically stratify all the archaeological finds and complete them for the sampling for various analyses which may be important for the reconstruction of basic branches of the former economy including agriculture, husbandry, manner of subsistence (archaeobotany, archaeozoology) and for the reconstruction of vegetation and biotope (along with the results of the palynological analysis).

The analysis whose methodology and preliminary results are presented in this paper includes an anthropological, 


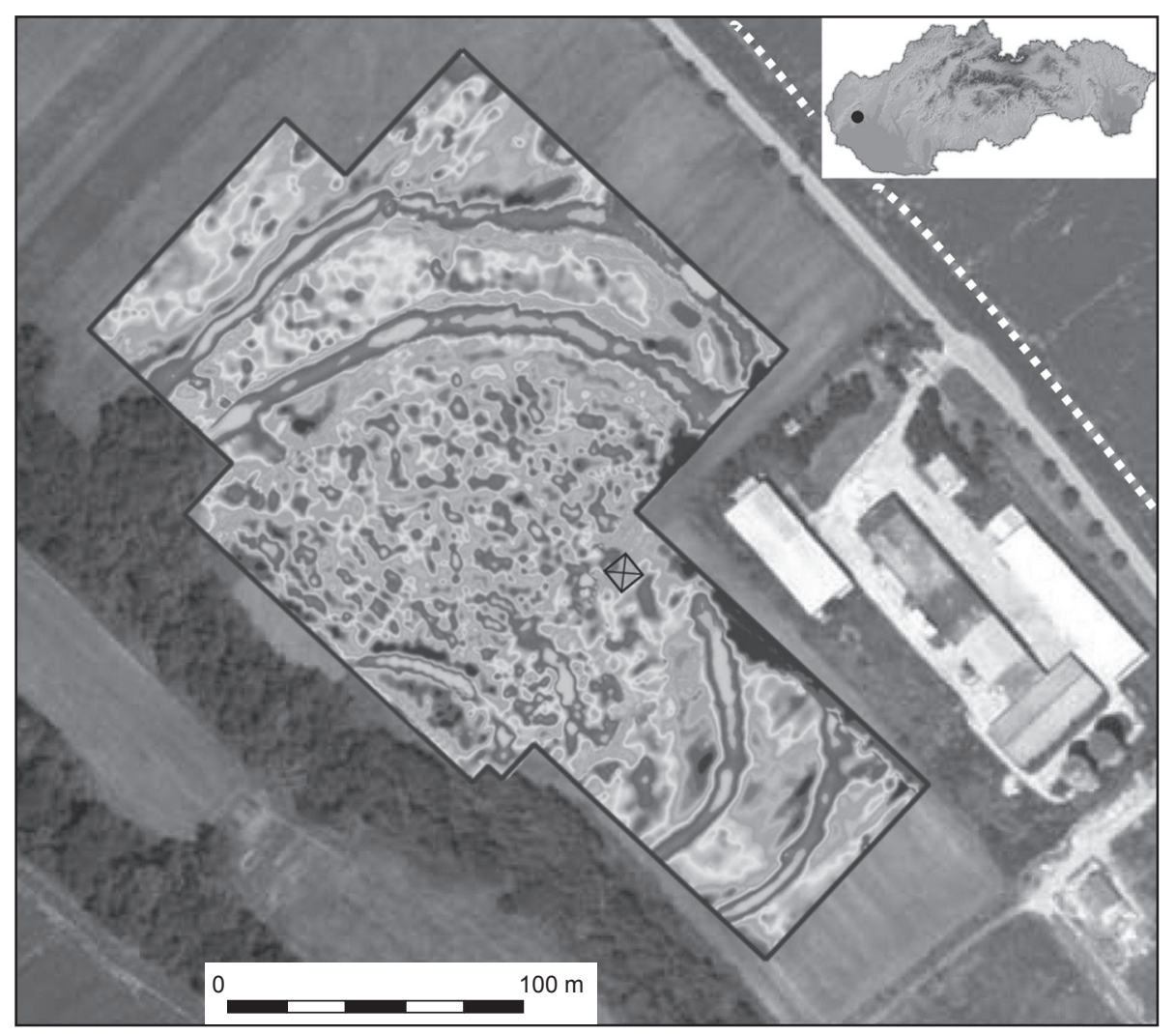

Figure 1. Budmerice. Map of magnetic anomalies on the site after J. Tirpák (2008), with additional marking of trench I position (black) and rescue excavation of I. Kuzma (white).

palynological and archaeobotanical analysis. The preliminary results of the analysis of the additional materials were not known by the time of the publication article and will be consequently published on another occasion. Out of the other planned analyses, the malacozoological, archaeozoological, archaeometric and petroarchaeologial analysis of pottery and stone tools, and the pedological analyses of the site shall be mentioned. We would also like to place an emphasis on the methods of absolute dating (dendrochronology, ${ }^{14} \mathrm{C}$ analysis of various organic materials).

Regarding the interesting finding situations, such as the finding of a skeleton in the settlement feature (a pit originally for storage), the partial aim of the anthropological analyses for the first seasons was to determine the available anthropological and palaeopathological information which would contribute to an interpretation of this kind of postmortem manipulation.

For the palynology, the aim of the analysis was to determine the season when the features were filled in, as well as to reconstruct the vegetation in the surrounding area.

Above all, the objective of the archaeobotanical, as well as of the entire environmental research on the site, is the systematic collecting of data which can also be used for statistical analysis in order that the results be as representative for the given site as possible. Apart from basic botanical identification and determination of plant assortment (both cultivated and gathered), we intend to define the site from the economic (palaeoeconomic) point of view. The taphonomic analyses and the ecology of the wild plant species should help accomplish this objective.
The current text is a preliminary example of the planned outputs and presents a number of the used methods and their results. We chose those which broadened our knowledge concerning the people living at the settlement, about their environment and about how they adapted to it. We do not, of course, consider these results to be final.

\subsection{History of the research on the site}

The site is situated in south-west Slovakia. Its cultural affiliation, based on a find of a complete vessel set and other objects from a disturbed feature, has been known since the 1950s (Točík 1962; Novotný, Fuhrherr 1971, 9). Since the site is situated on the frontiers of the territory of the Budmerice and Jablonec, it is introduced in the literature under the place names Budmerice, Budmerice/Jablonec or Jablonec. The name of the location varies, as well: Farárova rol'a, Predné pole, Sušička. In our texts we have a preference for the name Budmerice-Sušička.

The site is located near the watercourse of the Gidra which flows through the south-eastern part of the Trnava downs. The valley is formed by Holocene alluvial deposits - sheet washes. Pleistocene loesses and loess clays of polygenetic origin can be found in the surroundings. Neogene clay and marl formations covered by loess with a thickness of up to several metres are typical for the Budmerice and Jablonec region. In terms of the relief type, the site lies in the area of lowland downs. Brown earths are particularly typical for the Budmerice region (Fodor 1997).

The first finds were discovered in the 1950s and over the following decades only rescue excavations of a smaller 
Figure 2. Budmerice 2010, groundplan of trench I.

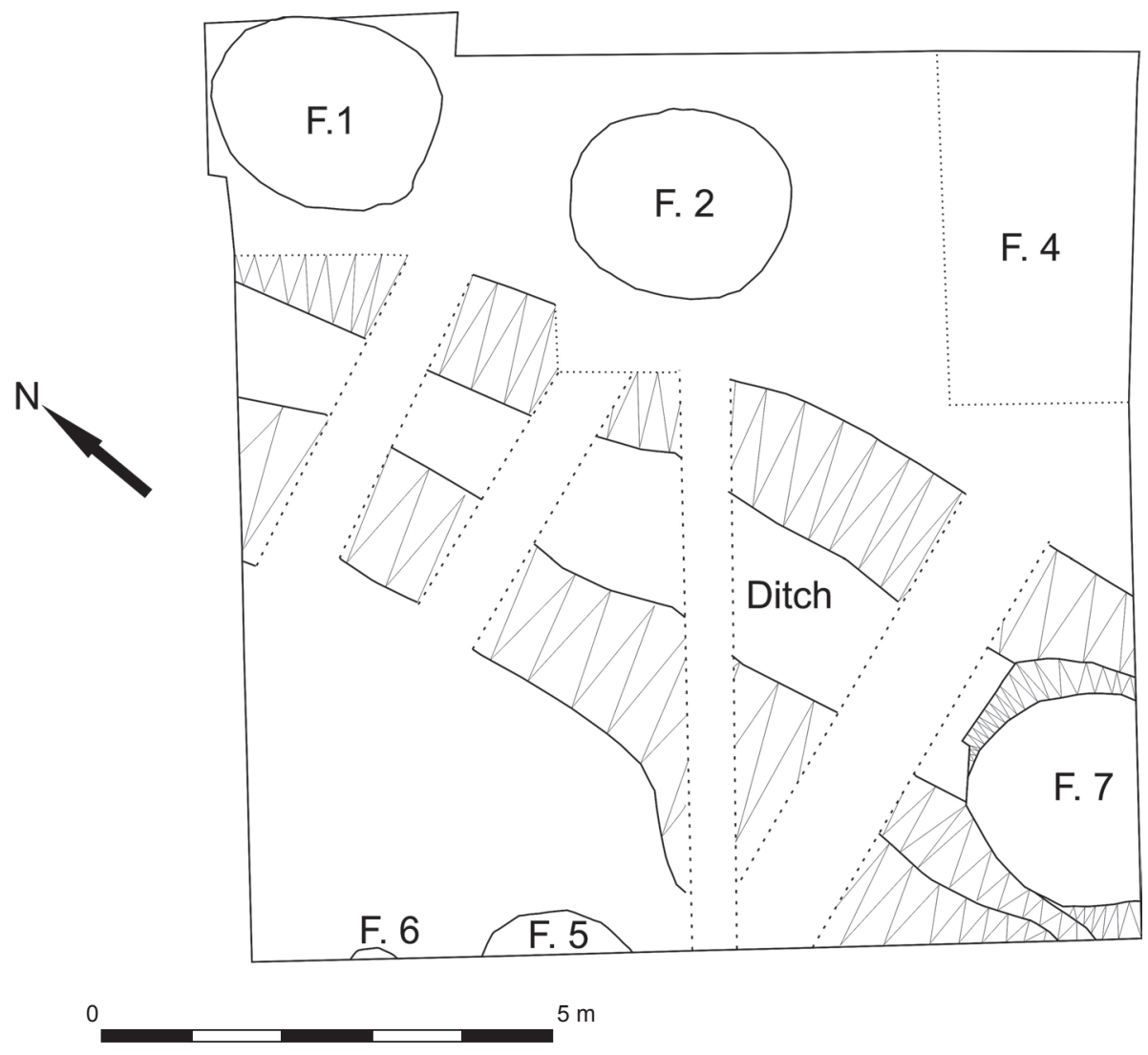

scope, with no records concerning their precise location, survey collecting activities, and non-destructive research were carried out at the site.

Their complete evaluation is apparently no longer possible at present, however, in future processing of the excavations we will try to make use of all accessible and preserved documentation to a maximum extent.

The most significant knowledge was brought by survey collecting and rescue excavations in 1976 and 1977, when the Mad'arovce culture, La Tène Period, Ludanice group, and upper medieval features were uncovered and finds from other periods were gathered (Farkaš et al. 1980). Additional survey collecting primarily yielded pottery fragments (Pichlerová 1971, 5-23; Bátora 1985; Bartík, Štrbík 1995; Bátora, Marková 1998; Oždáni 1998, 52; Figure 1:8), as well as a hoard of bronze objects (Bartík 1993). Aerial photography revealed the general course of ditch segments (Hanzelyová et al. 1995, Figure 34; Kuzma, Bartík 2009, Figure 1). The geophysical (magnetometric) measurements of the fortified settlement conducted in 2007 and 2008 at the initiative of the Malokarpatské múzeum in Pezinok by the Institute of Archaeology of the Slovak Academy of Sciences was a significant activity (Tirpák 2008). On the basis of geophysical measurements we are aware that the settlement was enclosed by four ditches of irregular semi-circular shapes which ended up at the edge of the terrace escarpment. The dark coloured course of the ditches as soil marks on the terrain surface can currently be observed in the area of the settlement and also minor traces of the ramparts at several spots.

Rescue excavations of the unfortified hinterland of the site also yielded remarkable results (Kuzma 2002) when the features of so-called Litzenkeramik were determined revealing the existence of the settlement up to the beginning of the Middle Bronze Age (Figure 1).

\section{Materials and methods}

The excavation method of our new systematic excavations was aimed in particular at obtaining the environmental data. Over the following seasons the method was rearranged and specified on the basis of the collected data to adjust the site conditions as much as possible. Trench I was opened with a size of $10 \times 10 \mathrm{~m}$ (Figure 2 ) in 2010 . It was set on a spot with a concentration of geophysical anomalies in the vicinity of the western corner of the area of the former dryer (Sušička). The grey-brown topsoil disturbed by agricultural activities (ploughing) was removed mechanically (by an excavator) up to a depth of $55 \mathrm{~cm}$. Below it a cultural layer of the same colour was encountered and was excavated stepwise by so-called "artificial" layers. During the excavations we delimited the $1 \times 1 \mathrm{~m}$ sectors for collecting the archaeobotanical samples from one other. In the northeastern half, the layer was excavated only up to a level where features began to be recognizable, i.e. to a depth of 
$80-80 / 90 \mathrm{~cm}$. In the eastern corner, at a depth of $65 \mathrm{~cm}$, a feature (no. 4) filled with dark soil was encountered which was bordered by decomposed burnt clay daub which was assumed to be the remains of part of an above-ground dwelling. The finding situation was conserved in order to be completely uncovered over the following seasons. Apart from feature 4 we identified five more features and a ditch which had not been identified before with non-destructive methods (neither geophysically nor from the aerial photographs). At the spot where the ditch was encountered, Aeneolithic material was found with the dark grey soil being different from the surroundings. At this place, the layers were excavated up to a depth of $100 \mathrm{~cm}$ where it was possible to identify the ditch sufficiently. The ditch was interpreted as an earlier structure and dated to the Early Aeneolithic. Its scientific evaluation is being prepared.

Additional features, apart from feature no. 3, are represented by storage pits. Only features 1, 2, and 7 were excavated, as features 5 and 6 extended outside the area of the trench. West of feature 4, a clay daub concentration was excavated which was labelled as feature 3. It is possibly related to a dwelling destruction, perhaps to feature 4, which lies in the immediate vicinity.

The features were excavated by artificial layers with in the first step always one half of a feature (where the archaebotanical samples were taken from each artificial layer). After the section documentation, the remaining half of the feature was excavated and archaeobotanically sampled by naturally deposited layers. The layers were also excavated stepwise, with artificial layers.

\section{Feature description}

\subsection{Feature 1 (Figure 3)}

The feature was situated in the northern corner of trench I. It was emptied beginning from a depth of $80 / 90 \mathrm{~cm}$ (measured from the terrain surface) downwards. It was first visible as an indistinct grey patch in the grey-brown soil above the loess virgin soil. The feature stands for a large storage pit with a flat bottom, pithead diameter $207-252 \mathrm{~cm}$, neck diameter $201-228 \mathrm{~cm}$ and bottom diameter $232-276 \mathrm{~cm}$. At its north-

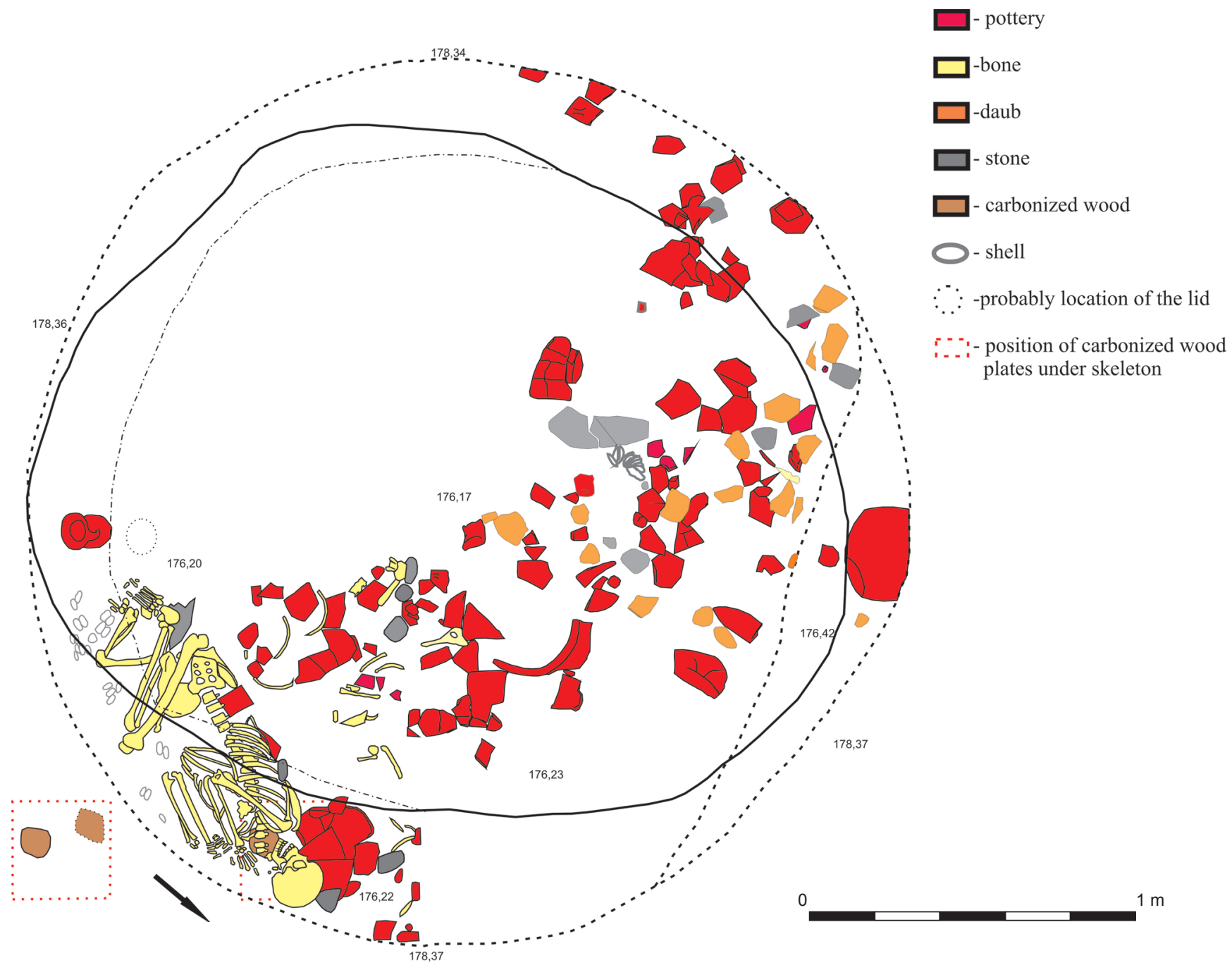

Figure 3. Budmerice 2010, feature 1. 

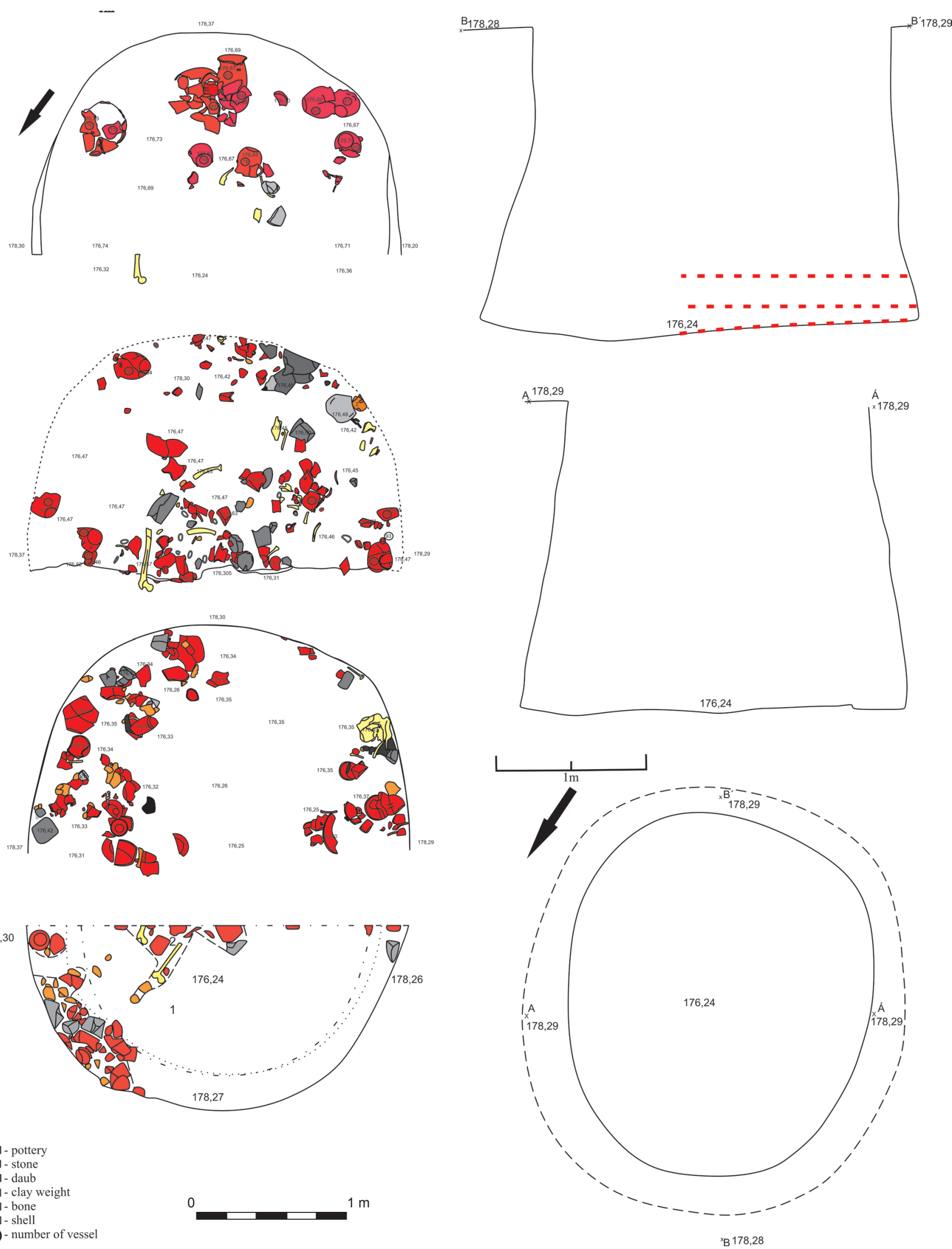

Figure 4. Budmerice 2010, feature 2. The figure displays individual levels of the feature with find accumulations. 
western part, feature 1 was disturbing feature 8 , identified by the grey-brown soil and sherds protruding from behind the feature borders. After the disturbance of feature 8, the north-western part of feature 1 was filled with isolating material - loess plaster - which prevented the contamination of the original pit content. Such an adaptation can be dated to prehistory, to the period immediately after digging feature 1 .

The feature was filled by two soil deposits. The upper one of a grey colour and a funnel shape originated presumably naturally. The second one, grey-brown, was formed by thin layers of an intentional, one-time deposit related to a human burial in the south-eastern half of the feature. The skeleton lay on its left side, facing north, with strongly bent legs. The skull lay on its right temple and was laid on a fragmented vessel. The accompanying material consisted of a massive mug by the legs of the deceased and a lid lying nearby. In the leg area, bivalve shells were accumulated. In the neck area, on its left side, a bronze spiral was found. Below the pelvis, a fragment of a grinding slab for cereal was placed. Beneath the skull, when removing cervical vertebrae, we encountered two carbonized wood fragments, pads of a quadratic shape (Figure 14). Moreover, apart from numerous vessel fragments, a bronze ear-ring (shifted in a finding position via bioturbation ?) was found in the deposit. At the bottom were a melting-pot fragment, slag, clay daub, perforated and originally stringed bivalve shells laid upon one other and arranged into a circle, parts of stone grinding slabs, stones, spindle whorls, and other objects. The feature also yielded animal bones, including dog bones.

\subsection{Feature 2 (Figure 4)}

The feature was situated by the south-eastern edge of trench I, immediately next to feature 1. It was emptied beginning from a depth of $80 \mathrm{~cm}$ (measured from the terrain surface) downwards. It was first visible as an indistinct grey patch in the grey-brown soil above the loess virgin soil.
The feature was a large cylinder storage pit with a pithead diameter 200-224 cm and flat bottom diameter 256-292 cm. The depth reached from the level of the first visibility was $212 \mathrm{~cm}$. The feature was filled by two soil deposits, similarly to feature 1 . The upper one of a grey colour and a funnel shape presumably originated naturally. In the upper part of this deposit, part of a child's skull was found. The second deposit, grey-brown, was formed by thin layers of an intentional, one-time deposit related to the noteworthy assemblage of the deposited objects.

In the lower half of the total depth, above the bottom and at the bottom, a set of 29 vessels was investigated, which were, apart from a few exceptions, found complete and intact. The vessels lay in three layers above one other, they were accumulated particularly in the south-western half of the feature, and were laid upside down, or on the side, rarely in a functional position. The vessels were only exceptionally incomplete. Out of the other six vessels, at least half of their bodies were preserved. In addition, larger fragments of lower vessel parts were discovered. In several cases a smaller pot (small mugs, cups, small amphoras) was inserted into a larger one (pots, large amphoras, cup); in one case a large pottery fragment was laid into a pot. One of the mugs placed inside the vessels contained a fish bone and bivalve shells which might be evidence for cooked liquid food. Pottery fragments represented a large inventory in the pit. Grinding slab fragments for cereals were also abundant, while crushers were fewer, loom weight was found as well. There was also clay daub and burnt stones among the finds. One of the moulds was for a bar-shaped ingot, another one for two needles, a ceramic nozzle, a melting-pot fragment, and a slag stand for evidences of metallurgical activities. Among the other objects there was a bronze ring, a boss, a breadshaped idol fragment and spindle whorls. The bone/antler industry, including an arrowhead, was scarce. Of interest is a clay daub block with fingerprints. At the pit bottom a layer

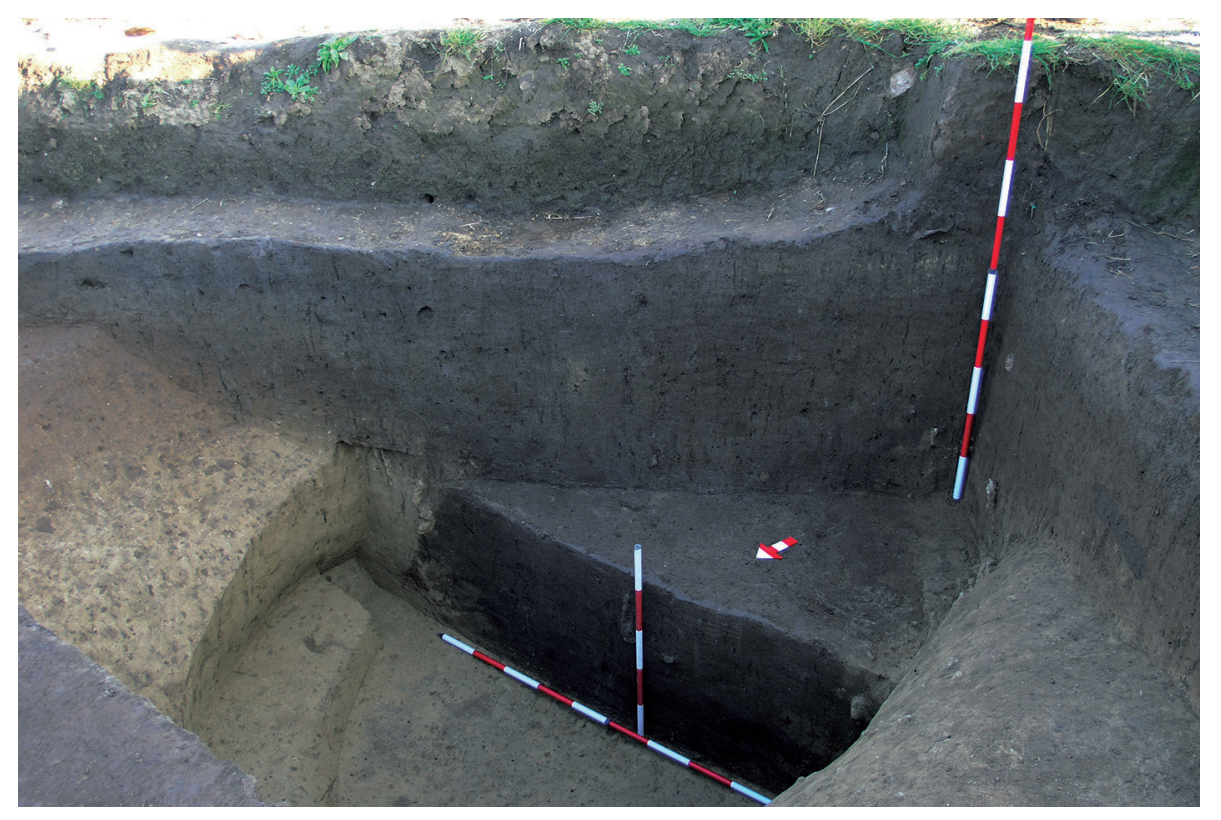

Figure 5. Budmerice 2010, feature 7. 
of carbonized cereals; at and within it, pottery and human bones representing several adult individuals were found. In the middle part of the pit lay the upper half of a femur, an additional femur was laid parallel and a fragment of a radius nearby, all belonging to adult individuals. The bones lay together with vessels, animal bones, and bivalve shells, from which several were perforated. Above the cereal layer and above the human bones lay the remains of carbonized oak timber.

\subsection{Feature 7 (Figure 5)}

The feature was situated in the southern corner of trench I in a superposition with an older ditch (in section E). It was visible as a dark grey patch, first encountered at the bottom of the ditch in the loess virgin soil, at a depth of $156 \mathrm{~cm}$ (measured from the terrain surface). It was originally a large conical storage pit with a pithead diameter $198 \mathrm{~cm}$ and a flat bottom diameter $276 \mathrm{~cm}$. There was dark grey soil above the feature in the south-eastern section of the ditch (at a depth of 177.07 MASL) certainly below, i.e. within the contexts surely ascribable to feature 7. However, this upper part of the feature fill was unrecognisable from the surrounding contexts (the ditch fill) at this level. The feature was only emptied in its northern half. It reached beyond the trench I limit but was not enlarged. The feature was filled with dark grey soil. The pottery inventory was rather poor and in general indistinct; the feature also contained clay daub, bones, malacofauna, charcoal and stones.

In features 1 and 2, finding situations were detected that evidence one-time events. In the first case, it was the deposition of a body, in the second case, the deposition of numerous artefacts, supposedly for ritual reasons (Jelínek in press; Jelínek, Vavák in press). Natural scientific analyses presented in this article also contribute to their interpretation.

\section{Anthropological analysis}

The human skeletal remains were excavated in the feature 1 and feature 2 . In the feature 1 there was discovered the complet skeleton of adult female lying on left side with flexed arms and legs. The skull was in unnatural position. In the feature 2 there were excavated two isolated femora with some taphomomic changes.

The remains were analysed by standart anthropological methods (Adsádi, Nemeskéri 1970; Buikstra a Ubelaker 1994; Ferenbach et al. 1979; Hanihara, Suzuki 1978; Herrmann et al. 1990; Işcan, Derrick 1984; Knußmann et al. 1988; Lovejoy 1985; Lovejoy et al. 1985; Meindl, Lovejoy 1985; Phenice 1969; Sjøvold 1990; Ubelaker 1987) and description of finding is below.

Table 1. Cranial measurements.

\begin{tabular}{lccc}
\hline Measurements & Anthropometric points & Dimension (in mm) & Categories \\
\hline (M1) Maximal cranial length & g-op & 183 & medial \\
(M1c) Metopion-opisthocranium length & m-op & 180 & \\
(M7) Length of the foramen magnum & ba-o & 34 & very narrow \\
(M8) Maximum cranial breadth & eu-eu & 132 & \\
(M9) Least frontal breadth & $\mathrm{ft}-\mathrm{ft}$ & 90 & \\
(M16) Breadth of the foramen magnum & & 25 & low \\
(M17) Basion-bregma height & ba-b & 136 & \\
(M20) Auriculo-bregmatic height & po-b & 112 & narrow \\
(M23) Horizontal circumference & & 501 & low \\
(M40) Basion-prosthion length & ba-pr & 94 & \\
(M45) Zygomatic breadth & zy-zy & 111 & \\
(M48) Upper facial height & n-pr & 63 & \\
(M50) Anterior interorbital breadth & mf-mf & 22 & \\
(M51) Orbital breadth & mf-ek & 37 & \\
(M52) Orbital height & & 33 & \\
(M54) Nasal breadth & apt-apt & 22 & \\
(M55) Nasal height & n-sn & 55 & \\
\hline
\end{tabular}

Table 2. Cranial indices.

\begin{tabular}{llrl}
\hline Cranial indices & & Categories \\
\hline (I1) Cranial index & (M8/M1) & 72.1 & dolichokran \\
(I2) Vertical cranial index & (M17/M1) & 74.3 & orthokran \\
(I3) Transverso-vertical cranial index & (M17/M8) & 103.0 & akrokran \\
(I13) Transversal fronto-parietal index & (M9/M8) & 68.2 & metriometrop \\
(I39) Upper face index & (M48/M45) & 56.8 & lepten \\
(I42) Orbital index & (M52/M51) & 89.2 & hypsikonch \\
\hline (I48) Nasal index & (M54/M55) & 40.0 & leptorrhin \\
\hline
\end{tabular}


Table 3. Racial identification from the mid-facial measurements

\begin{tabular}{lc}
\hline Mid-facial measurements & Dimensions (in mm) \\
\hline Naso-maxillo frontal height & 13.9 \\
Maxillofrontal breadth & 23.0 \\
Naso-zygoorbital height & 30.3 \\
Zygoorbital breadth & 53.0 \\
Naso-alfa height & 37.2 \\
Alfa-alfa breadth & 50.0 \\
\hline Mid-facial indices & \\
\hline Maxillofrontal index & 60.2 (Caucasoid) \\
Zygoorbital index & 57.2 (Caucasoid) \\
Alfa index & 74.5 (Caucasoid) \\
\hline
\end{tabular}

\subsection{Feature 1}

Sex: female.

Age: adultus I/adultus II, suggested age $c .30$ years of age.

Preservation state: almost all bones present, bone surface undisturbed.

Skull: The skull is complete, undisturbed, with a green stain present on the left processus mastoideus (behind auricle) and on the right zygomatic (jugal) arch. On lamina papyracea of the ethmoidal bone on the right side is the suspicion on inflammatory changes and the bone is partially taphonomically damaged. In general, the skull is medium long and extremely narrow. As concerns the skull index it belongs to the category of dolichocephalic skulls, the face
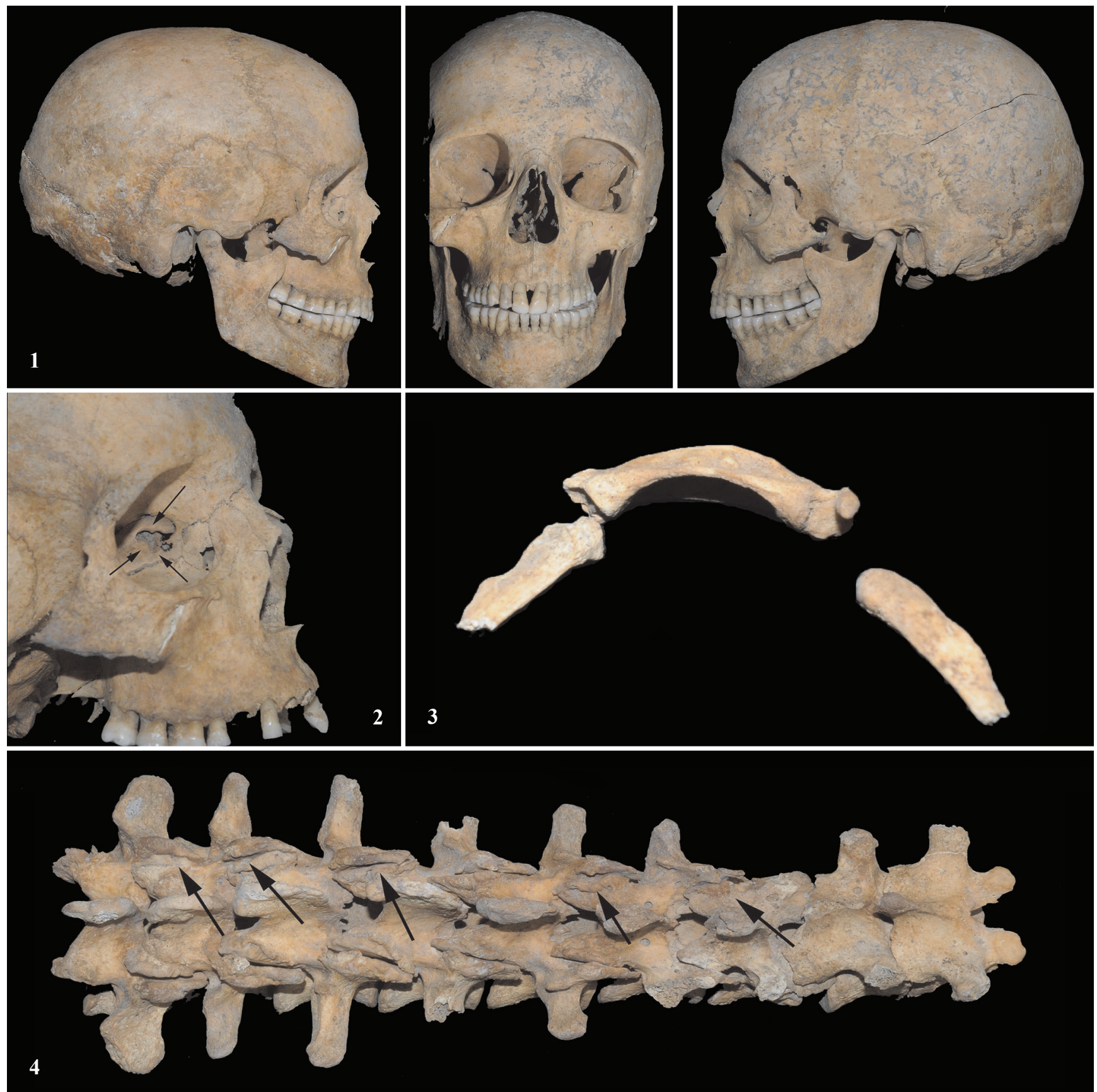

Figure 6. Budmerice 2010, feature 1: 1 - the skull of the individual (right lateral view, frontal view, left lateral view); 2 - lytic changes in right orbit; 3 - the hyoid bone; 4 - the lower part of thoracic vertebrae and the lumbar vertebrae with severe arthrotic changes in the intervertebral articulations. 
part is relatively narrow and low. The skull capacity was calculated at $1323.23 \mathrm{cc}$ (category euencephal - above the medium cranial capacity). Regarding the dimensions of the mid-face, the individual belonged to the Caucasian variety.
The skull measurements and indices are listed in Tables 1-3. A complete hyoid bone was preserved with the skull (Figure 6:3), its greater cornua were not fused, the right lesser cornu was fused with the corpus. The hyoid bone was not broken.
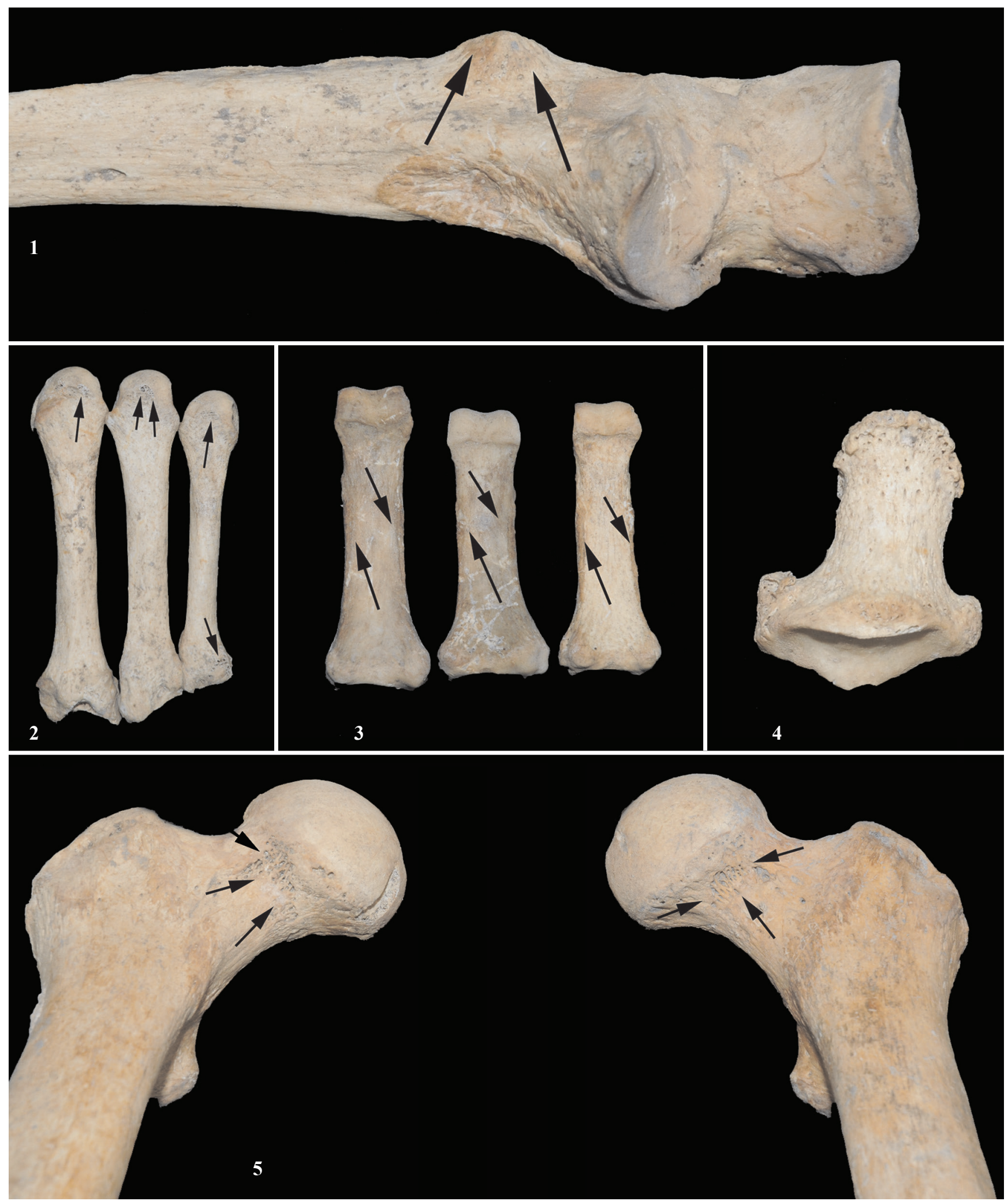

Figure 7. Budmerice 2010, feature 1: 1 - crista supinatoria on right ulna; 2 - the lesions on the metacarpal bones (right II., III., and IV. metacarpus); 3 - the enthesopaties on right hand fingers; 4 - hallux valgus; 5 - fossa Alleni on both femora. 
Teeth: Teeth were without caries, a calculus is present on the lower teeth and between the first two premolars of the upper teeth. Enamel hypoplasia was also present at this location.

Trunk skeleton: All vertebrae are present, even redundant thoracic vertebra were discovered (Th13, also with articular surfaces for the ribs). On the cervical vertebrae, marks of osteoarthritis (OA) were determined - on the body of $\mathrm{C} 7$, and on the left side of intervertebral articulations of the C4-5 vertebrae. Severe OA changes are present on the surfaces of lower thoracic vertebrae (Th10-13), where also inflammation marks are determinable on the lateral sides of the bodies and on the arches of the vertebrae (more severe on the right side). On the lumbar vertebrae, severe OA in intervertebral articulations was observed, although vertebrae bodies are intact regarding OA (Figure 6:4).

The sacrum has only four vertebrae (caudal shift as shown on Th13), two coccygeal vertebrae are ossified with the sacrum. There are weak signs of OA on facies auricularis.

The ribs are fragmented, without any pathological lesions and with only weak OA changes. The sternum is well preserved with asymmetric manubrium.

Upper limbs: weak OA is present on both scapulae. There is os acromii on the left side. Weak OA on both clavicles, enthesopathies are also visible on the right one.

Arm bones - weak OA only on the right humerus head, the enthesopathies are visible on both (more distinct on the right one). Lateral epicondilitis on the right arm bone (so-called tennis elbow) is also present. Measurements: H1 (maximal length) right $299 \mathrm{~mm}$, left $293 \mathrm{~mm}$; H2 (physiological length) right $295 \mathrm{~mm}$, left $288 \mathrm{~mm}$.

Ulnae - moderate OA changes of the elbow joint on both sides. Distinct crista supinatoria on the right, moderately developed on the left ulna. The taphonomic damage on processus styloideus of the left one is weak, although similar to the one on the radial bone. Measurements: U1 (maximal length) right $238 \mathrm{~mm}$, left $234 \mathrm{~mm}$; U2 (physiological length) right $210 \mathrm{~mm}$, left $207 \mathrm{~mm}$.
Radii - minor OA changes of articular surfaces on both sides. On the distal end on the lateral side of the left radius is a large hole which looks like taphonomic damage with moderate healing signs visible on the sides. Similar lesions are on os scaphoideum, on one phalanx, and on the ulna. Measurements: R1 (maximal length) right $215 \mathrm{~mm}$, left $213 \mathrm{~mm}$; R2 (physiological length) right $210 \mathrm{~mm}$, left $206 \mathrm{~mm}$.

Hand bones - on both the right and left sides, on the II., III., and IV. metacarpal bones by their heads from the dorsal side, a lesion is present (a dent with uncovered spongiosa, healed). Weak OA on the left side, one degree heavier on the right side. Distinct enthesopathies are present on the fingers of both hands. The V. metacarpus is oddly bowed on the left hand, probably having been broken and improperly healed. No calus is visible, thus if it was a fracture, then probably from childhood or early youth.

Lower limbs: Severe OA changes in the hip joints on both pelvic bones and inflammation changes are present on tuberositas postauricularis.

Femora-fossa Alleni is present on both, weak OA changes on the head and on condyli. Measurements: F1 (maximal length) right $420 \mathrm{~mm}$, left $419 \mathrm{~mm}$; F2 (physiological length) right $417 \mathrm{~mm}$, left $416 \mathrm{~mm}$. Patella with weak OA is present.

Tibiae - weak OA changes on the knee and ankle bones of both tibiae. On both tibiae the lateral accessory articular surfaces were present which usually originates due to frequent crouching or kneeling. Measurements: T1a (maximal length) right $347 \mathrm{~mm}$, left $347 \mathrm{~mm}$; T1 (maleolus-lateral condylus length) right $343 \mathrm{~mm}$, left $343 \mathrm{~mm}$; T1b (maleolus-medial condylus length) right $340 \mathrm{~mm}$, left $340 \mathrm{~mm}$.

Fibulae - without pathological changes. Measurements: Fi1 (maximal length) right $332 \mathrm{~mm}$, left $331 \mathrm{~mm}$.

Foot bones - on the tarsal bones and on the fingers, weak OA on both sides. The sezamoid bones are present on the right side. A lateral deviation of the great toe (hallux valgus) occurred on both feet.

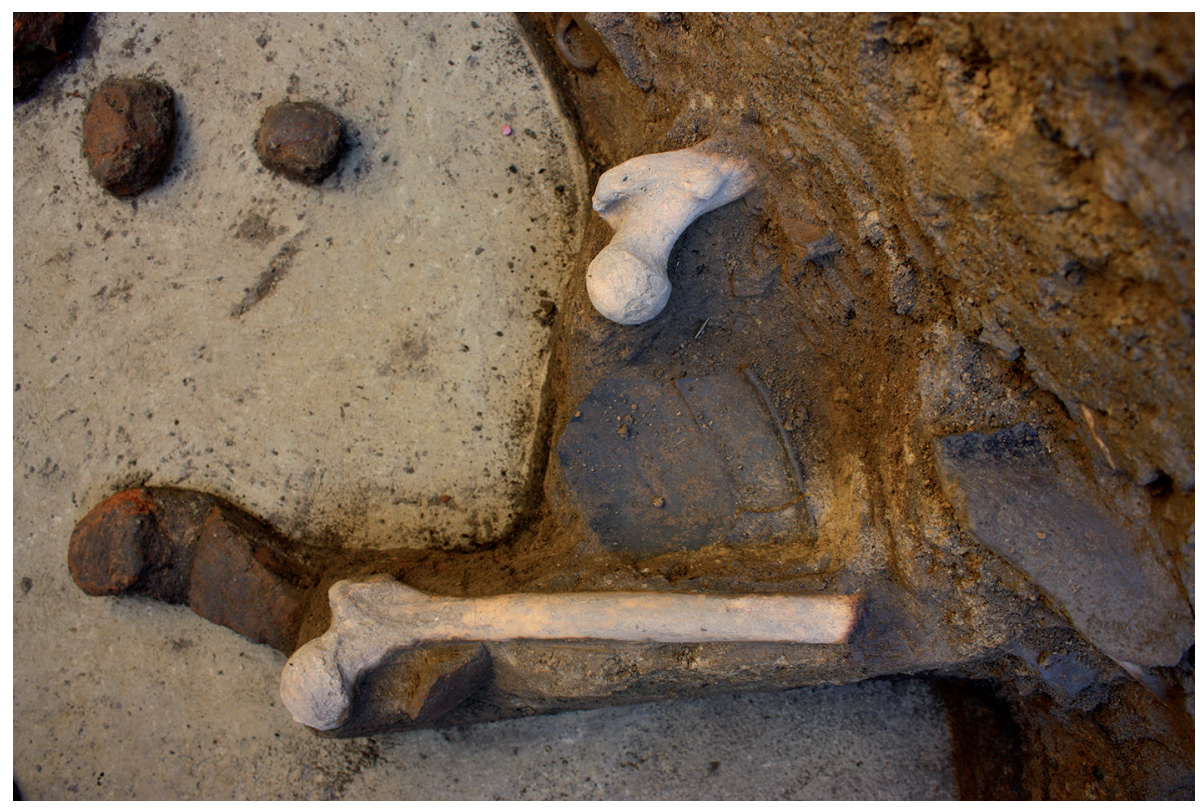

Figure 8. Budmerice 2010. Detail of the human bones from feature 2 . 

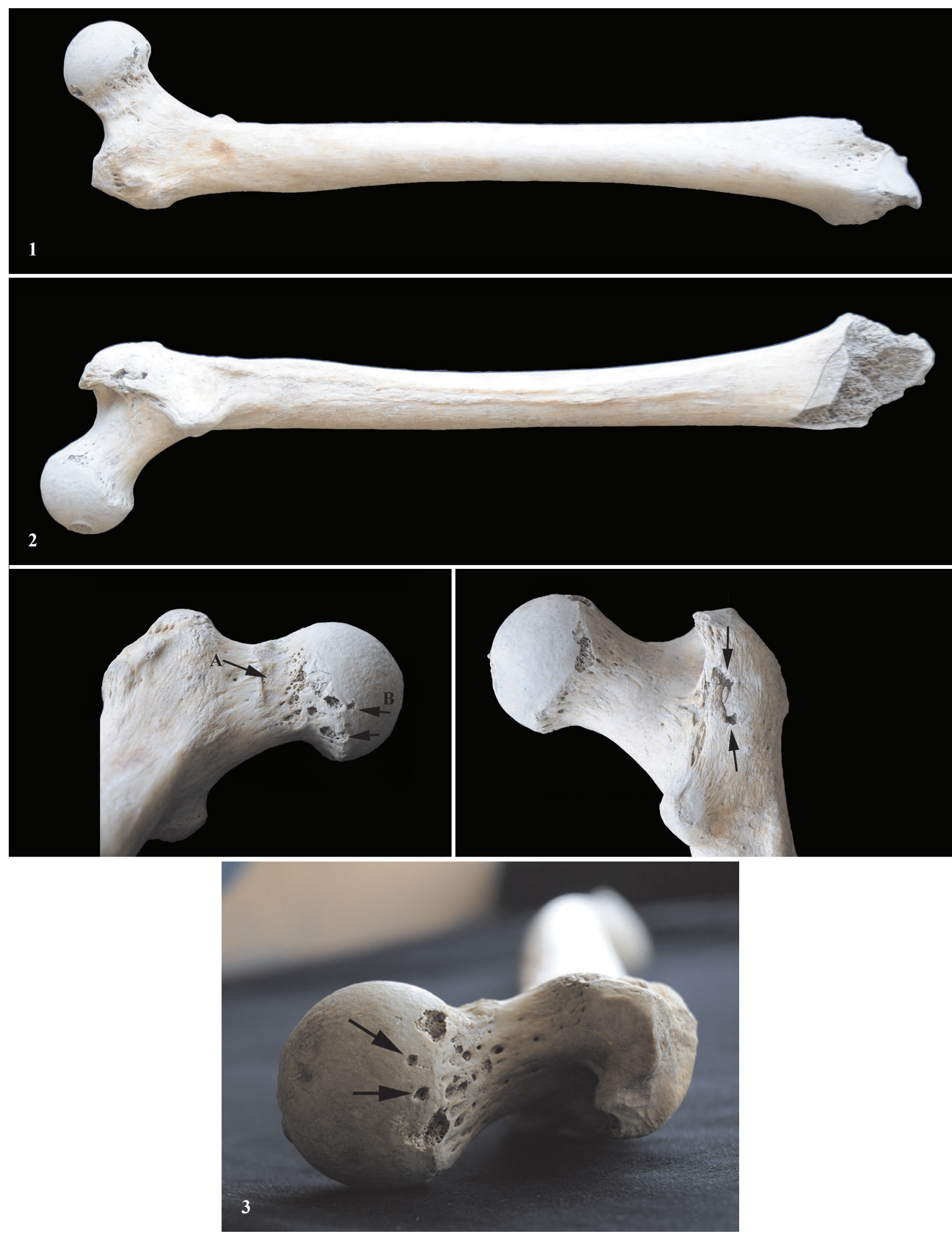

Figure 9. Budmerice 2010, feature 2: 1 - the right femur, general anterior view; 2 - the right femur, general dorsal view; 3 - the right femur, proximal end upper picture on the left: A - fossa Alleni, B - traces of carnivore gnawing on the femoral head; upper picture on the right - traces of gnawing on trochanter major; lower picture - traces caused by teeth on the upper side of the femoral head. 


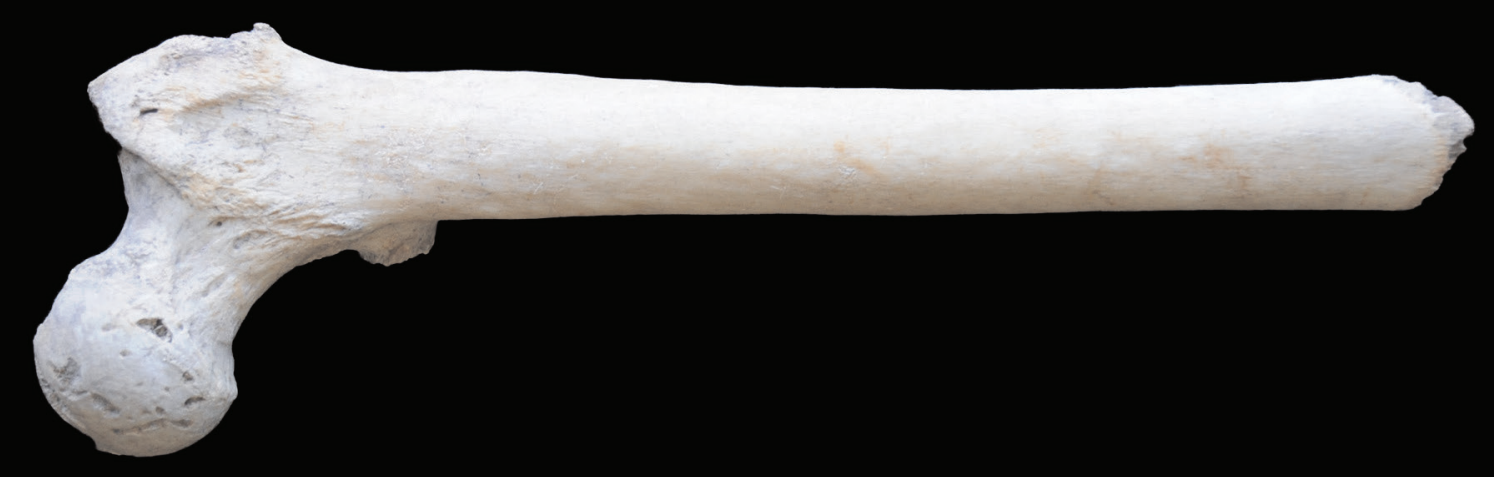

2
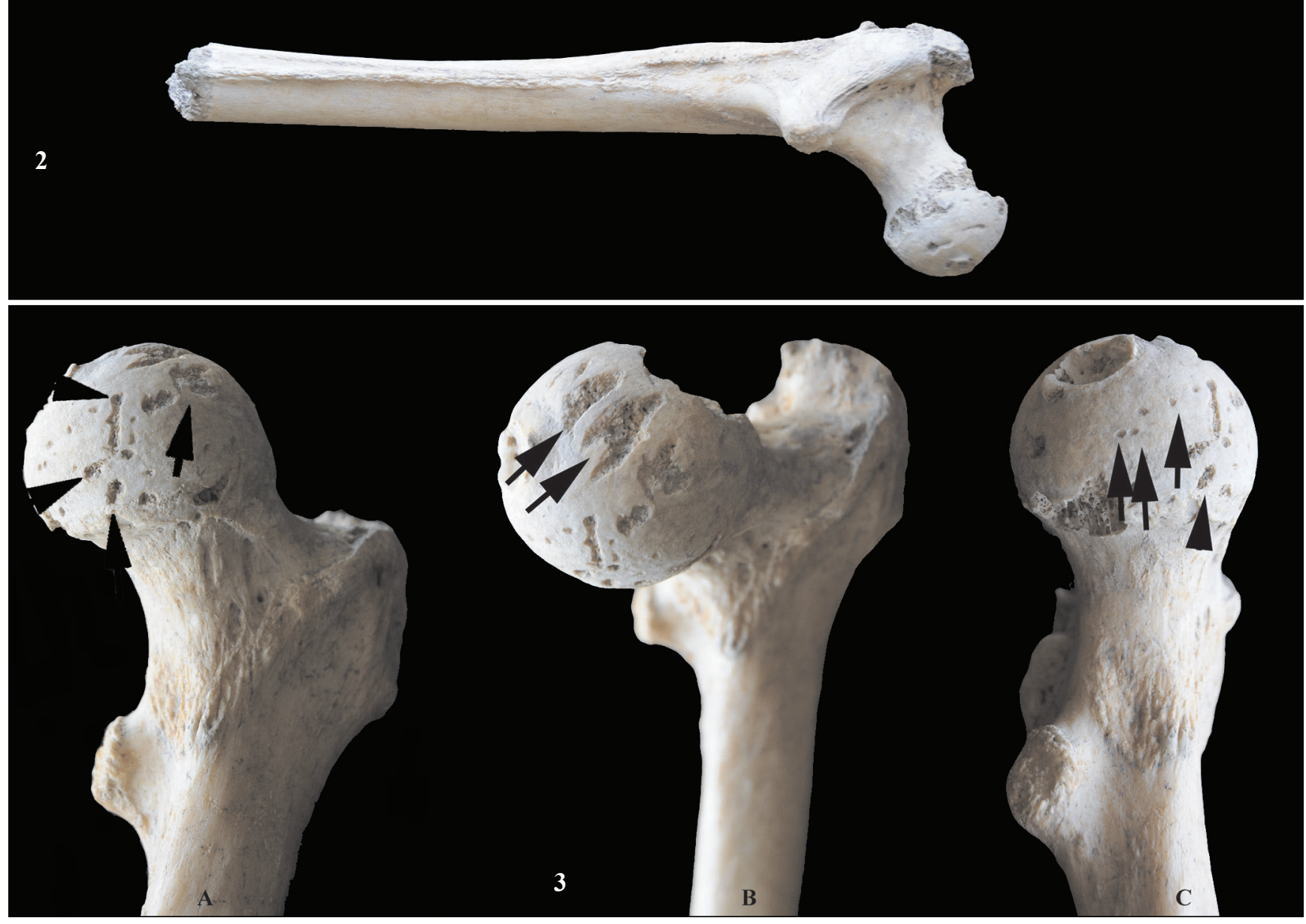

Figure 10. Budmerice 2010, feature 2: 1 - the left femur, general anterior view; 2 - the left femur, general dorsal view; 3 - the left femur, femural head with apparent traces of gnawing: $\mathrm{A}$ - anterior view; $\mathrm{B}$ - medial view; $\mathrm{C}$ - inferior view.

The body height was calculated at $155-163 \mathrm{~cm}$ (above medium tall female).

\subsection{Feature 2}

Two thigh bones were found in separate locations (Figure 8). Although they were right and left thigh bones, they most likely did not belong to one individual due to the morphological, epigenetic, and metrical characteristics.
Femur dexter - almost complete right thigh bone with a damaged distal part (Figure 9:1, 2). A less distinct linea aspera is present, as well as trochanter tertius and fossa Alleni (both epigenetic marks; Figure 9:3). In terms of pathological lesions, a weak OA is present on the head and also on the remains of the medial epicondyle. The measurements are listed in Table 4. As concerns the metrical and morphological analysis and discriminant equotions of measurements of 
Table 4. Measurements of the right femur.

\begin{tabular}{lc}
\hline Measurements & Dimensions (in mm) \\
\hline F1 Maximum length & $\mathrm{X}$ \\
F2 Physiological length & $\mathrm{X}$ \\
F6 Anterior-posterior diameter of the mid-shaft & 26.00 \\
F7 Medio-lateral diameter of the mid-shaft & 27.00 \\
F8 Circumference of the mid-shaft & 88.00 \\
F9 Subtrochanteric transverse diameter & 33.00 \\
F10 Subtrochanteric anterior-posterior diameter & 23.00 \\
F18 Medio-lateral head diameter & 44.00 \\
F20 Head circumference & 145.00 \\
10. I. PILASTRICUS (F6 : F7) & 93.30 \\
11. I. PLATYMETRICUS (F10 : F9) & 69.70 \\
Category & hyperplatymer \\
\hline
\end{tabular}
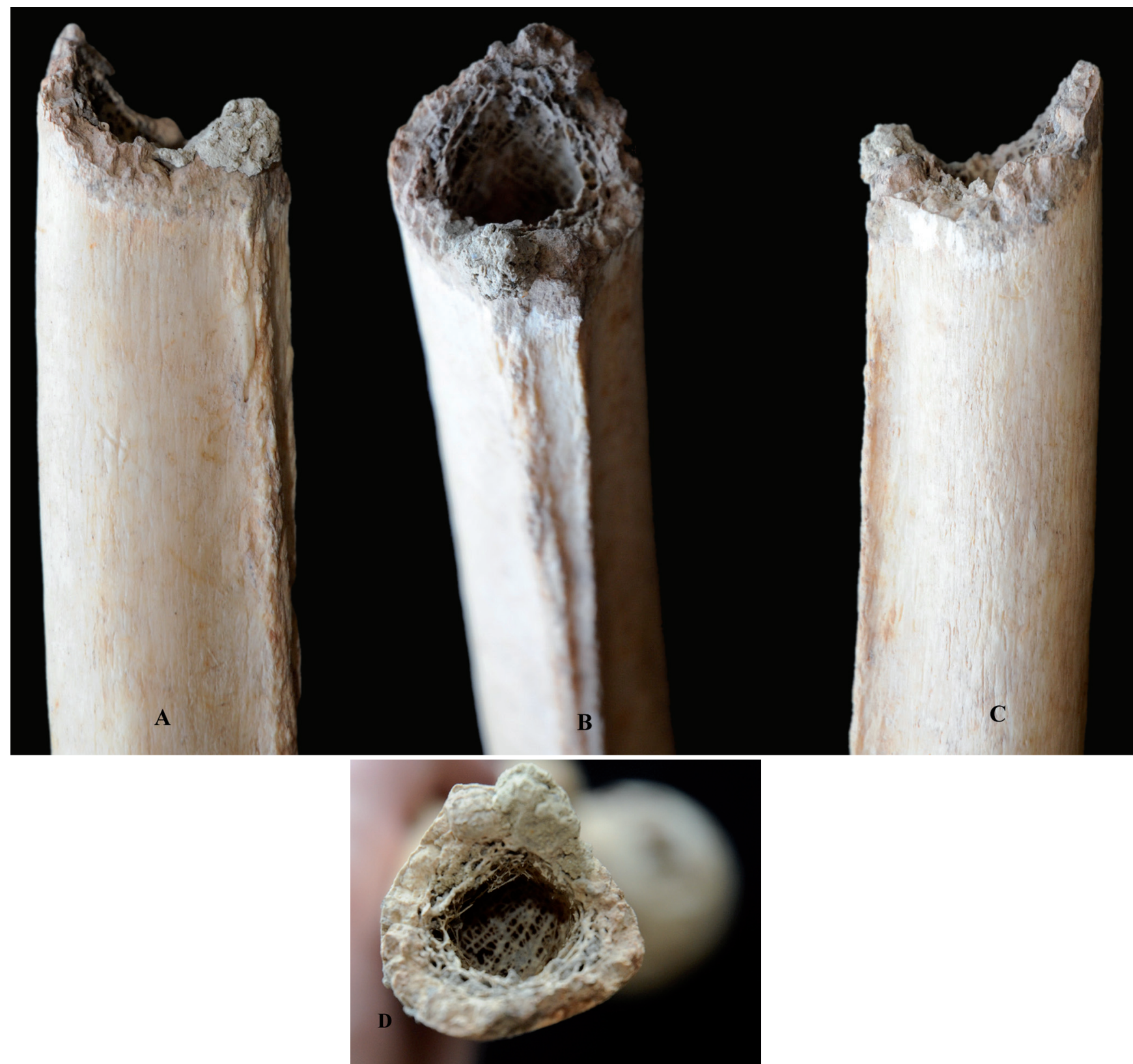

Figure 11. Budmerice 2010, feature 2: The left femur, detail of the distal part - A - medial view; B - dorsal view; C - lateral view; D - intra-medullary cavity view where $c .1-2 \mathrm{~cm}$ from the fracture line a spongious bone is formed. 


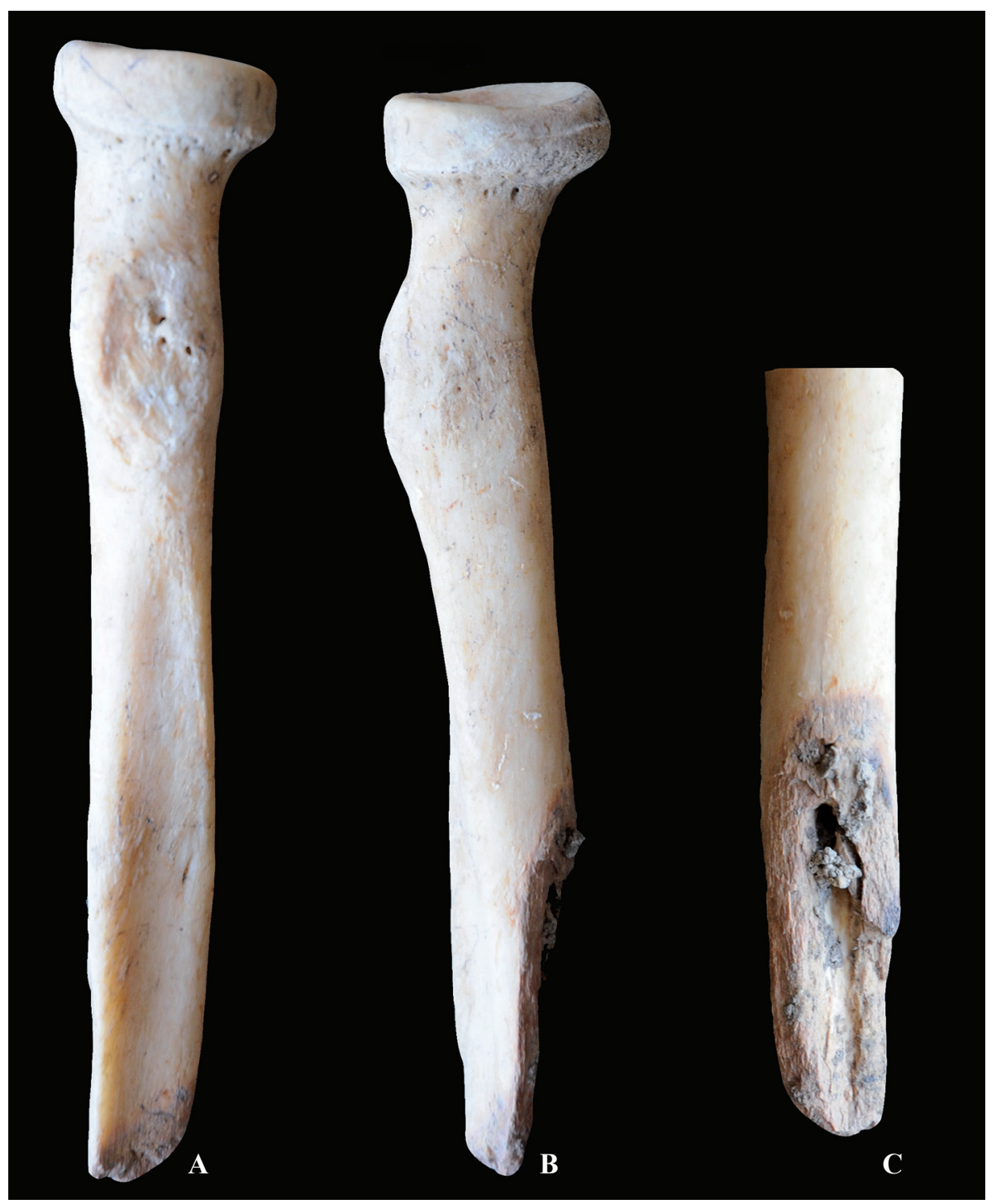

Figure 12. Budmerice 2010, feature 2. The bone no. 45 ; proximal end of radius sinister; A - volar view; B - lateral view; C - dorsal view and fracture line detail.

the head and of the middle part of the diaphysis, the bone belonged to an adult male individual. Traces of gnawing are apparent, probably left by a canid, on the head and on trochanter major (Figure 9:3). Damage to the distal part is postmortal and does not bear traces of gnawing.
Femur sinister - left thigh bone with a missing distal part (Figure 10:1, 2). The bone is exceptionally heavy which is most likely caused by the fossilization process. Linea aspera is distinct, trochanter tertius is indicated. Traces of gnawing are also present here on the head and on

Table 5. Measurements of the left femur.

\begin{tabular}{|c|c|}
\hline Measurements & Dimensions (in mm) \\
\hline $\begin{array}{l}\text { F1 Maximum length } \\
\text { M }\end{array}$ & $\mathrm{X}$ \\
\hline F2 Physiological length & $\mathrm{X}$ \\
\hline F6 Anterior-posterior diameter of the mid-shaft & 31.00 \\
\hline F7 Medio-lateral diameter of the mid-shaft & 28.00 \\
\hline F8 Circumference of the mid-shaft & 97.00 \\
\hline F9 Subtrochanteric transverse diameter & 35.00 \\
\hline F10 Subtrochanteric anterior-posterior diameter & 27.00 \\
\hline F18 Medio-lateral head diameter & $\mathrm{X}$ \\
\hline F20 Head circumference & 157 \\
\hline 10. I. PILASTRICUS (F6 : F7) & 110.71 \\
\hline 11. I. PLATYMETRICUS (F10 : F9) & 77.14 \\
\hline Category & platymer \\
\hline
\end{tabular}


trochanter major, traces after canines are visible (probably from a canid; Figure 10:3). The distal part of the diaphysis is broken (Figure 11). The character of the breakage indicates that the distal part could have been broken off postmortem, however, probably at the earliest one month after death. There is a transversely formed spongious bone in cavum medulare above the fracture line which might have been formed during tumorigenesis, assumedly located in the distal third of the thigh bone. The breakage of the distal part could have been related to the above-mentioned pathological process which could have weakened the bone (osteopenia or osteoporosis often occur as an accompanying effect). Based on the morphometric analysis, the bone belonged to an adult male. The measurable dimensions are listed in Table 5. On the fracture line, by linea aspera, there is a clay lump "baked together" with a bone that could not be removed by washing. The darker colour of the fracture line could have been caused by burning at a low temperature, but is more likely an infiltration of the "naked" bone by soil chemical substances as the rest of the bone do not show any traces of burning or cremation.

Radius sinister - the left radial bone from the only proximal part was preserved. Regarding morphological characteristics and the absence of osteoarthritis, the radial bone probably belonged to a young adult male. The distal part was broken off perimortally or relatively soon after the death of the individual, the fracture line has a dark colour (Figure 12). "Baked together" clay remains are also present here and the darker fracture lines can be explained by a similar process as on the left femur.

From the upper part of the deposit comes an occipital squama of an immature individual without pathological lesions and intentional interventions. The soil is bound to the bone, particularly from the inner side.

Table 6. All identified pollen types and their ecological characterization.

\begin{tabular}{|c|c|c|c|c|c|c|c|}
\hline \multirow[t]{2}{*}{ Pollen type } & \multicolumn{6}{|c|}{$\begin{array}{l}\text { Number of identified pollen } \\
\text { grains in each features }\end{array}$} & \multirow[t]{2}{*}{ Prevailing type of biotop } \\
\hline & $1 / 1$ & $1 / 2$ & $1 / 3$ & $2 / 1$ & $2 / 2$ & $2 / 3$ & \\
\hline$\overline{\text { Abies }}$ & 1 & 3 & & & & & forest \\
\hline Pinus & 5 & 2 & 3 & 2 & & & forest, nutrient poor soils \\
\hline Quercus & 2 & & & & & & oak-hornbeam forest, oak forest, hard floodplain forest \\
\hline Ulmus & 1 & 1 & 2 & & & & hard floodplain forest, oak-hornbeam forest \\
\hline Salix & & & & 1 & & & floodplain forest, alongside of streams \\
\hline Sum of trees (Arboreal pollen) & 9 & 6 & 5 & 3 & & & \\
\hline Apiaceae undif. & & 2 & & 2 & & & broad ecological amplitude \\
\hline Artemisa & 1 & 7 & 1 & & 1 & 1 & ruderal places, meadows \\
\hline Campanula trachelium type & 1 & & & & & & forest edges, trampled habitats, weed \\
\hline Carduus type & & 1 & & & & & meadows, pastures, ruderal places \\
\hline Chenopodiaceae & 10 & 15 & 2 & & 2 & 1 & broad ecological amplitude; generally ruderal places, waste deposits \\
\hline Centaurea jacea type & & 2 & & & & & meadows, pastures, dry grasslands \\
\hline Cerealia undif. & 1 & 18 & & 2 & 3 & 3 & fields \\
\hline Cirsium & 2 & 6 & & & & & wet meadows, fields, ruderal places \\
\hline Cyperaceae & 40 & 67 & 30 & 13 & 12 & 8 & broad ecological amplitude; generally open wetter habitats \\
\hline Fenestratae & 8 & 5 & 6 & 2 & 2 & & generally open land \\
\hline Mentha type & & 1 & & & & & meadows, grasslands, wetlands, \\
\hline Papaver rhoeas type & 2 & 3 & & & & & fields, dry grasslands \\
\hline Plantago lanceolata type & & 1 & & & & & pastures, meadows, dry grasslands \\
\hline Plantago media/major & 1 & 2 & & & & & pastures, meadows, ruderal places \\
\hline Poaceae & 3 & 53 & 5 & 1 & 2 & & broad ecological amplitude, generally dryer open habitats \\
\hline Polygonum aviculare type & 2 & 13 & 1 & 2 & & & trampled habitats \\
\hline Ranunculus acris type & & 1 & & & & & broad ecological amplitude; generally wet meadows \\
\hline Rosaceae undif. & & 2 & & & & & broad ecological amplitude \\
\hline Rubiaceae & & & & 1 & & & broad ecological amplitude; generally open land \\
\hline Senecio type & 1 & 7 & & & & & broad ecological amplitude; generally open land \\
\hline Spergula arvensis & & 2 & & & & & fields \\
\hline Succisa type & 1 & & & & & & wet meadow \\
\hline Viola tricolor type & 1 & & & & & & fields, ruderal places \\
\hline Sum of herbs (Non Arboreal pollen) & 74 & 214 & 45 & 24 & 24 & 14 & \\
\hline Total sum & 83 & 220 & 50 & 27 & 24 & 14 & \\
\hline Micro-charcoal $<40 \mu \mathrm{m}$ & 103 & 115 & 95 & 65 & 10 & 5 & \\
\hline Micro-charcoal $>40 \mu \mathrm{m}$ & 27 & 30 & 25 & 45 & 5 & 33 & \\
\hline
\end{tabular}




\section{Palynological analysis}

In total, six samples for palynological analysis were collected from features 1 and 2. The reason for their retrieve was the occurrence of unusual finding situations encountered after excavations and the collection of one half of each feature. From the feature with the skeleton (feature 1), the samples $1 / 1,1 / 2,1 / 3$ were collected, while from feature 2 , the samples $2 / 1,2 / 2,2 / 3$ were gathered. The samples were retrieved from the feature section just above the bottom of the feature. At the sampling spot, $c$. $5 \mathrm{~cm}$ thick layer of soil was removed from the wall of the section which could have been contaminated by recent pollen. Afterwards, the intact feature fill was taken, with sterile tools, and packed into PVC bags. The samples were labelled, stored in a cooled container, and sent for analyses. The sampling spots were documented.

\subsection{Laboratory analysis of the samples}

Material for pollen analyses (each of a volume $1 \mathrm{~cm}^{3}$ ) was processed by standard techniques (Faegri, Iversen 1989). Samples containing clastic materials were pre-treated with a cold concentrated HF (hydrogen fluorid) for 24 hours and then processed by a $\mathrm{KOH}$ (potassium hydroxide) solution followed by acetolyses procedure for 7 minutes in boilingwater with final mounting in glycerol. Pollen and spores were identified and calculated under a Leica DM 2500 microscope at $400 \times$ magnification. Because of low quantities of palynomorphs, at least 3 microscopic slides were counted in each sample. However, the sum of the pollen counts ranged between 14 and 220 pollen grains in the sample.

Pollen and spores were identified according to Beug (2004) and according to pollen atlases (Reille 1992; 1995; 1998). The nomenclature of the pollen types follows Beug (2004).

Apart from pollen grains, spores and various non-pollen features, an abundance of micro charcoal particles was counted in the individual samples.

Percentage pollen diagrams could not be created due to the small number of identified pollen features and therefore the results are presented in Table 6 .

In all the analysed samples, herbaceous plants prevailed. In feature 1 , the pollen grains were preserved in a quantitatively and qualitatively larger amount. In feature 2, the pollen grains were present in a relatively small number.

\subsection{Feature 1}

According to Table 6, the pollen spectrum from feature 1 is dominated by herbaceous pollen types with prevailing Cyperaceae.

In the scarce record of arboreal pollen, conifers prevailed - pine (Pinus), less fir (Abies). Among deciduous trees, the pollen grains of elm (Ulmus) and two pollen grains of oak (Quercus) were recorded.

Contrary to arboreal pollen, the herbaceous taxa were present in a much larger number. Apart from Cyperaceae, a higher amount of Poaceae, Fenestratae, Artemisia, Centaurea jacea t., Succisa t., Plantago media/major were recorded. The presence of Polygonum aviculare t., Plantago lanceolata t., Viola arvensis t., Spergula arvensis and Cerealia undif. indicates the presence of meadows and human induced habitats near the site.

The vicinity of human settlement is also indicated by the abundance of micro-charcoals present in all the analysed samples.

\subsection{Feature 2}

The pollen record from feature 2 is somewhat poor (Table 6). From the arboreal species only two pollen grains of pine (Pinus) were identified. From the deciduous species, one pollen grain of willow (Salix) was recorded.

From the herbaceous species, the pollen grains of the Cyperaceae family, less of Poaceae, predominated. Other documented pollen grains indicate the presence of human induced habitats (Cerealia undif, Artemisia, Chenopodiaceae, Polygonum aviculare t.). Similarly to the previous feature, a larger amount of micro-charcoals was calculated.

\subsection{Reconstruction of vegetation in the vicinity of the features}

Due to unsatisfactory quantities of the counted pallynomorphs, the reconstruction of the surrounding vegetation is extremely vague and disputable. However, based on a pollen analysis from features 1 and 2 we suggest that the site was situated in the vicinity of a settlement, ruderal habitats, fields and meadows, as well as in the vicinity of a water course.

In terms of the composition of arboreal pollen types, Pinus prevailed with Abies occurring to a lesser extent. Conifer pollens - particularly pine (Pinus) pollens - have an extraordinary ability to fly. Moreover, the pollen productivity of the pine tree is rather high and its amount in pollen diagrams is often overestimated (e.g. Prentinece 1985; Sugita 1994; Sugita et al. 2009). We would therefore suggest their transport from the nearest Little Carpathians Mts., as well as their local occurrence near the studied site. The pollen grains of elm (Ulmus), oak (Quercus), and willow (Salix) probably indicate the presence of hard floodplain forests along the water courses.

In terms of herbacesous pollen types, the prevailing pollen grains of Cyperaceae were recorded in both analysed features. The presence of Cyperaceae in the pollen profiles obtained from natural deposits (peat, wetland) is generally viewed as an indication of wetter habitats, whereas the presence of Poaceae is associated with a dryer habitat (e.g. Krippel 1986). As for the pollen spectras from other features (such as archaeological features), Cyperaceae may reflect the occurrence of several types of open habitats (dry grasslands, wetland, etc.). We therefore consider them as the record of an open landscape.

The composition of other non-arboreal pollen types indicates the overall presence of a human induced landscape. The high amount of Fenestratae, Artemisia, Centaurea jacea t., Succisa t., Plantago media/major suggests meadows. Ruderal plants, such as Polygonum aviculare t., indicate trampled habitats and cultivated land. Pollen grains of Plantago lanceolata $\mathrm{t}$. are commonly connected with grazed 
grasslands (Behre 1981; Gaillard 2007). The occurrence of Cerealia undif. and weeds, such as Viola arvensis t. and Spergula arvensis, indicates the presence of crop fields in the nearest vicinity of the site. The vicinity of human settlement is also indicated by the abundance of micro-charcoal present in all the analysed samples.

The low amount of arboreal pollens is quite strange; in an un-forested environment they usually form c. 50\% of the total sum of all the terrestrial pollen grains (Magyari et al. 2010; Svenning et al. 2002). We therefore assumed that this fact could reflect the season period when the features were filled.

\section{Archaeobotany}

At the present time, the retrieved material is the object of an analysis which is not completed as yet. We therefore present here principally only the strategy and method of sampling and the extraction of the plant macroremains from the sediment samples.

\subsection{Archaeobotanical material retrieve}

No archaeobotanical material assemblage comes from the previous research activities carried out on the site. Our excavations were consequently the first time when a retrieve of (not only) archaeobotanical material took place. When choosing the sampling strategy and method, we first and foremost considered the aim of recording objectively as representative a material spectrum as possible. Keeping such an objective in mind, the only option was to choose the systematic sampling which also became our primary strategy. When choosing the strategy and the method, we followed the standard method and the European archaeobotanical research methodology (cf. Jones 1991; Jacomet, Kreutz 1999; Pearsall 2000; Lityńska-Zając, Wasylikowa 2005; Hajnalová, Varsík 2010 etc.). The selected system of archaeobotanical research employed at the site of Budmerice was consulted with M. Hajnalová. We are truly grateful to her for the expert advice she provided.

\subsection{Archaeobotanical sampling}

The excavated area (archaeological trench) was divided into a net of regular quadrants/squares, each $1 \times 1 \mathrm{~m}$ in size. Out of those, the sediment samples were collected systematically in periodical intervals (scatter and point sampling, Figure 12). During the first excavation season (2010), the sampling in the square net was executed on a chessboard scheme, i.e. each second quadrant/square was sampled for the sediment. Apart from horizontal identification, the samples were also differentiated by the depth in the following way. In the part of the trench where no archaeological feature was detected, the area was excavated by artificial layers, each with a thickness approximately 10-15 cm. From each such layer within the particular chessboard square, one sediment sample was collected. On the area where archaeological features were detected, it was in exceptional cases possible to also define the samples according to the natural layers. Where the archaeological contexts/layers could be distinguished, the samples were taken from the original layers which were excavated in connection with their natural/original shape, thickness, and course in the field (not following the artificial layers as in the previous case; Figure 13). However, in the majority of cases the layers were not identifiable from the start, thus we usually continued sampling by artificial layers at the given depth interval. Each sediment sample taken from the field had to have at least 201 volume, excluding the cases where it was not possible to sample such a volume of the sediment (vessels, thin layers, etc.). Exceptionally, the complete remains of the feature fills were collected (e.g. feature 2). If extraordinary contexts were encountered which did not fit into the used sampling system, the so-called additional sampling method was employed when the sample was collected out of the system (e.g. vessel fills, isolated charcoal samples, column sampling, etc.).

As of 2011 (the second research season), the sampling methodology was partially adjusted in a way that each square of the net and each layer in the depth interval $10-15 \mathrm{~cm}$ was sampled. For each sample the minimal volume of sampled sediment was set at $10 \mathrm{l}$. In this season, the bottom of the excavated feature (no. 4) was not reached during the archaeological works, and deposition layers mostly were primarily excavated from the upper parts of the feature. During the 2012 campaign, the lower half of the feature was reached where the existence of a one-time intentional deposit was assumed. The squares were consequently divided into halves (with a width of $50 \mathrm{~cm}$ ), so that a more precise

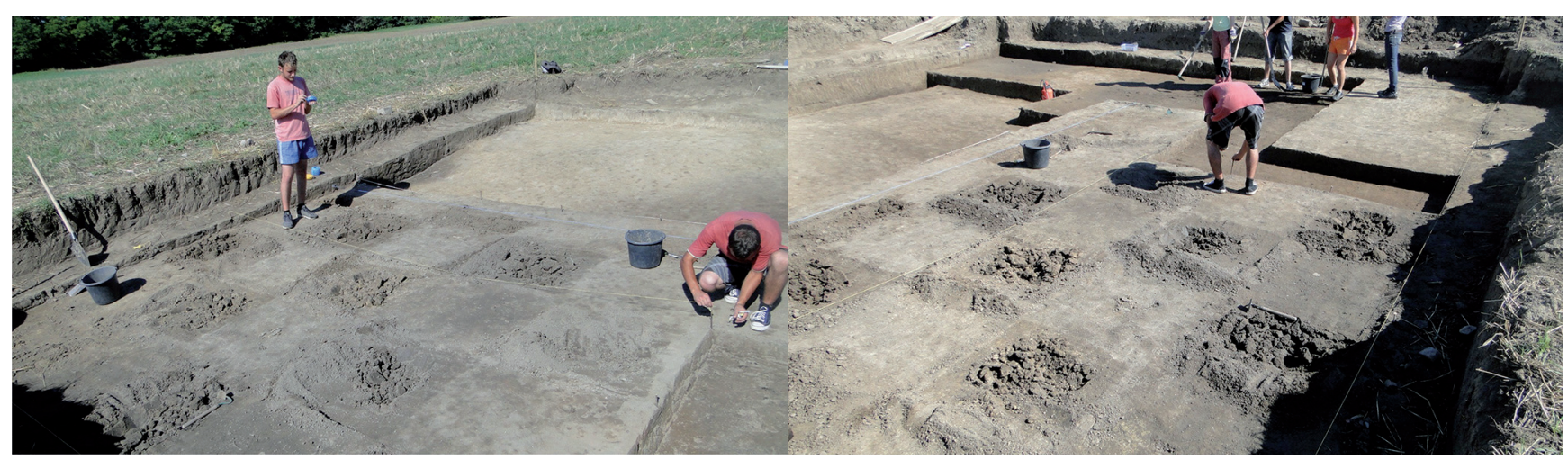

Figure 13. Budmerice 2010. Systematic archaeobotanical sampling following the delimited square net. 


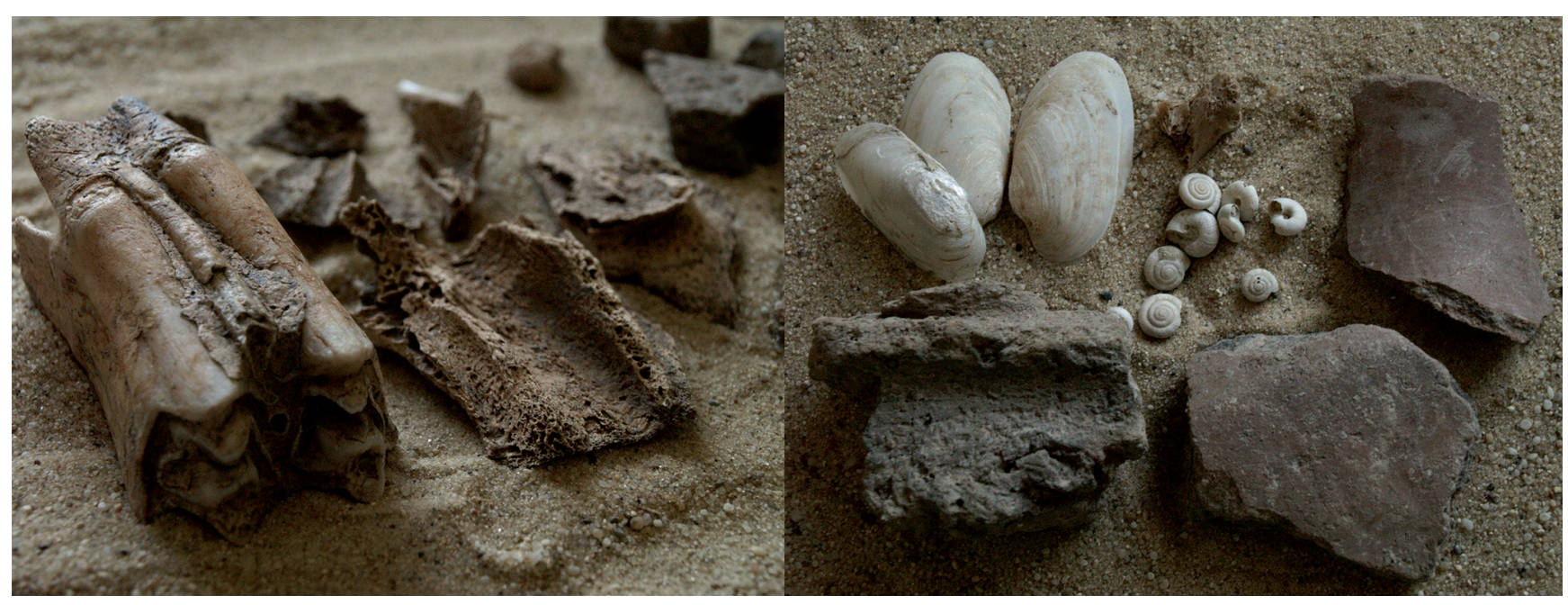

Figure 14. Budmerice 2010. Small finds from processed archaeobotanical samples detected during sorting the heavy residuous fractions (HR) after flotation.

definition of the sample position in the feature could be made (point sampling for collecting the spatial data). At present, the retrieved material is being processed and the results will be presented in the nearest future.

\subsection{The extraction of macroremains}

Primary sample processing, involving their thorough labelling, flotation, sorting, and drying, took place at the archaeological base of the nearby excavated site. Immediately after the sediment sample was retrieved and labelled in the field, the samples were transported to the base where the flotation tank was assembled for the needs of plant macroremains extraction. During its construction we followed the archaeobotanical practice and notes of M. Hajnalová (pers. comm.), and also the research and instructions of M. Nesbitt (1995).

In this manner, with mechanical flotation in the tank, the majority of the retrieved samples were processed. The method of mechanical flotation is the most suitable as well as the fastest for the processing of large amounts of voluminous samples. As has clearly already been stated above, a smaller amount of the samples, particularly those representing the vessel fills, had a volume of only around 21 . These were processed manually. The employed flotation method is therefore referred to as combined, because it enables the combination of individual methods (here mechanical flotation in the tank and manual flotation) according to the sample character, in order that the best results be achieved (cf. Hajnalová, Hajnalová 1998).

Various types of finds were obtained by extraction. We were above all interested in plant macroremains where we recorded carbonized (cereal grains, charcoals) and also uncarbonized (weed and tree seeds) macroremains.

Apart from the plant macroremains, other finds were recorded as well. Animal bones were particularly frequent: fragments of larger bones and entire bones of small rodents and amphibians, Gastropoda and bivalves. We also found pottery and clay daub fragments, particularly bronze slag/ ingots, etc. (Figure 14). All the above-mentioned remains, organic and inorganic, carbonized and uncarbonized,were recorded by flotation and also by sorting the heavy residuous fractions (HR).

The method of systematic sampling and flotation immediately after the retrieve turned out to also be extremely productive because it could record even small archaeological finds which were not spotted by the archaeologist in the field. Regarding the concentration and composition of the material recorded by the flotation, we can adjust the sampling method in the field and raise or reduce the volume of the sampled sediment, in order that the extracted plant macroremains also be statistically representative.

\section{Summary of the results}

The obtained results broaden the number of environmental and anthropological data from the settlements. Out of the material assemblages of Mad'arovce culture this category of information is only known to a minimal extent (cf. Hajnalová 2012; Jelínek, Vavák in press). They enable an improved knowledge of the finding situation at the site, but in a broader sense also contribute to the solving of certain theoretical questions which are being asked in the research of the Early Bronze Age.

The palynological analysis completes the knowledge on the environment of the region (cf. Hajnalová 1990). However, the primary objective of the sampling was to specify, with the help of the analysis of the sampled pollens, the season when the first layer in both features 1 and 2 was filled, as it involved extraordinary finding situations (the skeleton in feature 1 , the intentionally deposited vessels and other artefacts in feature 2) which cannot be connected with a cultic practice (Jelínek 2009; Palátová, Salaš 2002, 103). The season of the year when the deceased were laid into the graves is the subject of the important question in the research on the skeletons in the settlement features. One theory would view the settlement burials as provisional acts during the winter when it was not possible to dig out the regular grave 
pits (Pavúk, Bátora 1995, 48, 49; Kovárník 2010, 55). In contrast, after M. Salaš (1990) the deceased were laid into emptied storage pits during the spring or summer when the pits lost their primary function. Based on the results of the palynological analysis of the pollen samples from the bottom of feature 1 , the female skeleton was laid into the empty pit during the summer time. This result is certainly extremely productive for the discussion, however, for a general interpretation it will be necessary to also test other features palynologically with human remains in the future (Jelínek in press).

The palynology was also a weighty source of information in the interpretation of feature 2. In order to identify the approximate time of the burial of the body, the flower phenology of the identified pollen spectrum was used (Bertová ed. 1982; 1984; 1985; 1992; Futák ed. 1966; Goliášová ed. 1998; Goliášová, Šípošová ed. 2002; 2008; Goliášová, Michálková ed. 2006). The presence of numerous species of meadows and weeds, as well as the presence of crops would seem to imply the summer time of the body burial (Table 7). For example, Centaurea jacea, Centaurea stoebe, and Succisa pratensis all blossom from July to September. In addition, the flower phenology of the weeds implies the same period of the year; Viola arvensis blossoms from April to September, Viola tricolor from May to September, Papaver rhoeas also from May to September, Spergula arvensis from July to October.

The fact that the body was deposited in the feature at some point during the period from June to September is also evidenced by the minor presence of arboreal pollens from species which predominantly blossom during the spring time.

The pit was interpreted as a deposition place of so-called sacral waste, or as a sacrifice to chthonic deities (Jelínek in press). This event is suggested to have occurred in the summer, in all probability after the harvest. It is possible that already burnt cereals were poured into the feature. Although no distinctive traces of burning were recorded on the feature walls, baked together cereal lumps and the presence of microcharcoals suggest that the cereals came into contact with fire, as it did not smoulder in the pit without an oxygen supply. Folklore tells us about the ritual destruction of the first cereals or of the old storages after the harvest (Eliade 2004, 327). Burnt cereals from feature 2 might indicate that similar ritual practices were already performed in prehistory.

In addition, the anthropological analysis significantly contributes to the interpretation of the finding complexes and at the same time broadens the sparse database of determined individuals from the settlements of Mad'arovce

Table 7. Flower phenology of identified pollen taxa.

\begin{tabular}{|c|c|c|c|c|c|c|c|c|c|c|c|c|}
\hline \multirow[t]{2}{*}{ Pollen type } & \multicolumn{12}{|c|}{ Month } \\
\hline & $\mathrm{I}$ & II & III & IV & $\mathrm{V}$ & $\mathrm{VI}$ & VII & VIII & IX & $\mathrm{X}$ & $\mathrm{XI}$ & XII \\
\hline Abies & & & & $\mathrm{X}$ & $\mathrm{X}$ & & & & & & & \\
\hline Apiaceae undif. & & & & $\mathrm{X}$ & $\mathrm{X}$ & $\mathrm{X}$ & $\mathrm{X}$ & $\mathrm{X}$ & $\mathrm{X}$ & $\mathrm{X}$ & & \\
\hline Artemisia & & & & & & & $\mathrm{X}$ & $\mathrm{X}$ & $\mathrm{X}$ & $\mathrm{X}$ & $\mathrm{X}$ & \\
\hline Campanula trachelium type & & & & & & $\mathrm{X}$ & $\mathrm{X}$ & $\mathrm{X}$ & $\mathrm{X}$ & & & \\
\hline Carduus type & & & & & & $\mathrm{X}$ & $\mathrm{X}$ & $\mathrm{X}$ & & & & \\
\hline Chenopodiaceae & & & & & & $\mathrm{X}$ & $\mathrm{X}$ & $\mathrm{X}$ & $\mathrm{X}$ & & & \\
\hline Centaurea jacea type & & & & & & $\mathrm{X}$ & $\mathrm{X}$ & $\mathrm{X}$ & $\mathrm{X}$ & & & \\
\hline Cerealia undif. & & & & & & $X$ & $\mathrm{X}$ & & & & & \\
\hline Cirsium & & & & & & & $\mathrm{X}$ & $\mathrm{X}$ & $\mathrm{X}$ & & & \\
\hline Cyperaceae & & & & & & $\mathrm{X}$ & $\mathrm{X}$ & $\mathrm{X}$ & & & & \\
\hline Fenestratae & & & & $\mathrm{X}$ & $\mathrm{X}$ & $\mathrm{X}$ & $\mathrm{X}$ & $\mathrm{X}$ & $\mathrm{X}$ & $\mathrm{X}$ & & \\
\hline Mentha type & & & & & $\mathrm{X}$ & $\mathrm{X}$ & $\mathrm{X}$ & $\mathrm{X}$ & $\mathrm{X}$ & $\mathrm{X}$ & & \\
\hline Papaver rhoeas type & & & & & $\mathrm{X}$ & $\mathrm{X}$ & $\mathrm{X}$ & $\mathrm{X}$ & & & & \\
\hline Pinus & & & & & $\mathrm{X}$ & $\mathrm{X}$ & & & & & & \\
\hline Plantago lanceolata type & & & & & $\mathrm{X}$ & $\mathrm{X}$ & $\mathrm{X}$ & $\mathrm{X}$ & $\mathrm{X}$ & $\mathrm{X}$ & & \\
\hline Plantago media/major & & & & & & $\mathrm{X}$ & $\mathrm{X}$ & $\mathrm{X}$ & & & & \\
\hline Poaceae & & & & & $\mathrm{X}$ & $\mathrm{X}$ & $\mathrm{X}$ & $\mathrm{X}$ & $\mathrm{X}$ & & & \\
\hline Polygonum aviculare type & & & & & & $\mathrm{X}$ & $\mathrm{X}$ & $\mathrm{X}$ & $\mathrm{X}$ & $\mathrm{X}$ & & \\
\hline Quercus & & & & $\mathrm{X}$ & $\mathrm{X}$ & & & & & & & \\
\hline Ranunculus acris type & & & & & $\mathrm{X}$ & $\mathrm{X}$ & $\mathrm{X}$ & $\mathrm{X}$ & $\mathrm{X}$ & & & \\
\hline Rosaceae undif. & & & & & $\mathrm{X}$ & $\mathrm{X}$ & $\mathrm{X}$ & $\mathrm{X}$ & $\mathrm{X}$ & & & \\
\hline Rubiaceae & & & & & $\mathrm{X}$ & $\mathrm{X}$ & $\mathrm{X}$ & $\mathrm{X}$ & $\mathrm{X}$ & & & \\
\hline Salix & & & $\mathrm{X}$ & $\mathrm{X}$ & $\mathrm{X}$ & & & & & & & \\
\hline Senecio type & & & & & $\mathrm{X}$ & $\mathrm{X}$ & $\mathrm{X}$ & $\mathrm{X}$ & $\mathrm{X}$ & $\mathrm{X}$ & & \\
\hline Spergula arvensis & & & & & & $\mathrm{X}$ & $\mathrm{X}$ & $\mathrm{X}$ & $\mathrm{X}$ & $\mathrm{X}$ & & \\
\hline Succisa type & & & & & & $\mathrm{X}$ & $\mathrm{X}$ & $\mathrm{X}$ & $\mathrm{X}$ & & & \\
\hline Ulmus & & & $\mathrm{X}$ & $\mathrm{X}$ & $\mathrm{X}$ & & & & & & & \\
\hline Viola tricolor type & & & & & $\mathrm{X}$ & $\mathrm{X}$ & $\mathrm{X}$ & $\mathrm{X}$ & $\mathrm{X}$ & $\mathrm{X}$ & & \\
\hline
\end{tabular}




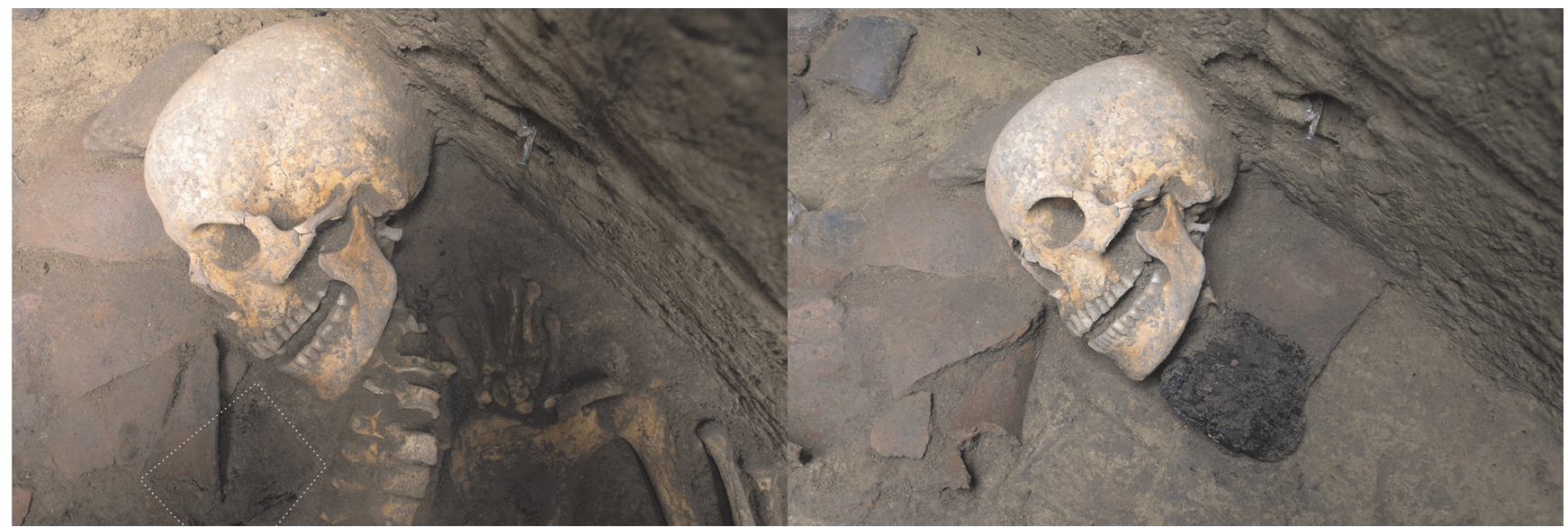

Figure 15. Budmerice 2010. Detail of the skull of the skeleton from feature 1. On the left one charred pad is marked by white dashed line. On the right there is the second pad, originally lying beneath the skeleton.

culture (Jelínek in press; Jelínek, Vavák in press). Based on the analysis of the presence of OA and enthesopathies it can be stated that the middle-aged female used to carry out fairly difficult work. The individual markers imply lifting and carrying loads and intense housework. The individual was most likely right-handed. The turned head position in the grave supposedly originated secondarily. There were no traces of violent head turning or throttling traces on the vertebrae (the hyoid bone was complete). The death of the female having been from natural causes is also evidenced by the demographic analyses at the cemetery of the Mad'arovce culture in Jelšovce where female mortality culminated right at the age of adultus I (Jakab 2007; Daňová 2010, 121). The unnatural skull position was in all probability caused by the decomposition of a wooden board whose remains were found when lifting the skeleton (Figure 15).

Importance can be attributed to two femora out of the isolated bones from feature 2 which were laid intentionally at the cereal layer together with additional artefacts. They imply that during the Early Bronze Age the human remains were manipulated in a ritual way which might not have been related to anthropophagy. Finds of isolated bones at settlements of Mad'arovce culture are relatively common, however, their anthropological evaluation is only rarely published or lacks detailed information concerning their finding circumstances (e.g. Ambros 1971; Furmánek, Jakab 1997). Various anomalies are also known from the cemeteries which provide evidence of either intentional excarnation (Ernée 2000) or interventions into the graves, which might not necessarily be connected with grave robbery

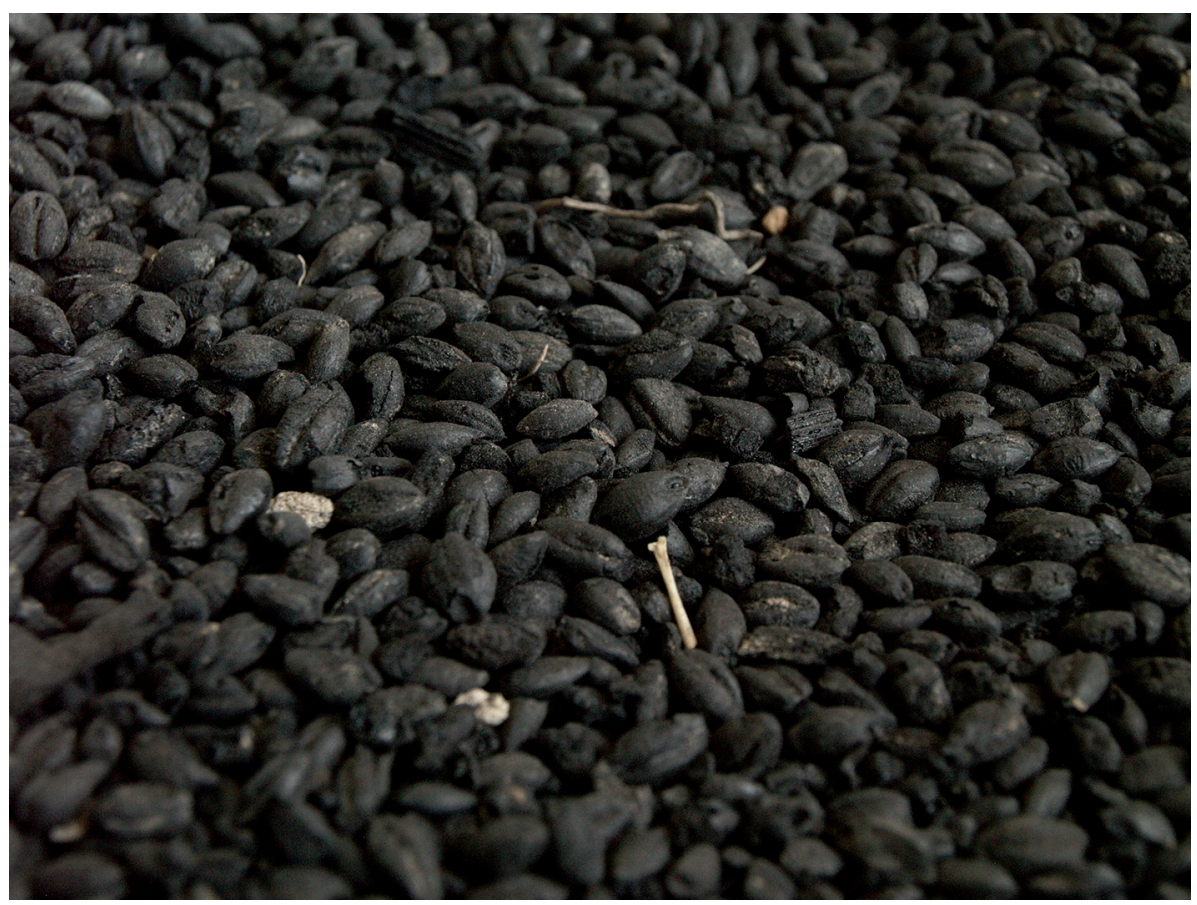

Figure 16. Budmerice 2010. Charred cereal grains of common barley (Hordeum vulgare), retrieved from feature 2 . 
but could have a connection with non-profane collecting of bones (Daňo 2002, 57).

Another human skeleton was already known from the site previously (Farkaš et al. 1980). This was a juvenile individual, in all probability a female. As the feature with this skeleton was disturbed by a mechanism, the significance of the finding situation was somewhat impoverished. Circa $500 \mathrm{~m}$ east of the settlement, the cemetery of its inhabitants was identified (Pichlerová 1971, 12) which is at present in all probability destroyed by the modern built-up area of family houses. Nevertheless, M. Pichlerová rescued three graves from this cemetery, one cremation and two inhumation graves. They were not anthropologically analysed, however. Apart from research on the skeletons coming from the area of the settlement, it will be desirable in the future to focus on searching and rescuing those grave complexes which might have been preserved within non-built-up places.

As mentioned above, at present, the sorting of the retrieved archaeobotanical material and plant macroremains identification is being carried out. The material is only in its processing stage due to the large volume of the samples. Only primary results are consequently presented here which, despite their partial character, influence the adjustment of the methodology of archaeobotanical research for the next several seasons.

Despite the fact that the larger volume of well-preserved carbonized cereal grains (several hundreds of grains) was obtained by sampling and flotation, they only occurred in such an amount in one archaeological feature (no. 2). The composition of cereal grains (Figure 16) which were retrieved from the feature, in terms of their species and concentration, has enriched the knowledge about cultivated crops both from our site as well as from the researched period of the Early Bronze Age. The analysis has served to demonstrate that in feature 2 predominantly (c. $85 \%$ ) grains of common barley (Hordeum vulgare) occurred which in all probability indicate the remains of a cereal reserve (Jelínek et al. 2011, $1,2)$. The occurrence of barley in the Bronze Age is common (cf. Hajnalová 1993, 97; Hajnalová 2012, 73, 74 etc.), however, at the Budmerice site the barley grains data set is of an extraordinary amount compared to other cereal grains (wheat; Triticum spp.) found in the feature. As was stated above, no burning traces were detected so it can be assumed that the already carbonized cereals were poured into the pit (feature 2). In connection with other finding circumstances, the deposition of the cereal grains could have also been an element of a certain ritual activity (Jelínek et al. 2011, 1, 2). It is only an isolated find of this kind, however, within the excavated area. During the second research season, no other similarly rich find was discovered within additional trenches, despite the fact that the sampling was changed from a chessboard system to a sampling of each quadrant of the delimited net (point sampling). In the retrieved samples from all three seasons, carbonized cereal grains occurred in addition to both barley and wheat (Triticum spp.) which were recorded in scarcer amounts. In several cases, the samples occurred with a more striking concentration of wild plant seeds (several hundreds of seeds). Since the laboratory analysis has not been completed as yet, it cannot be stated with certainty whether the wild plant seeds (weeds) belong to prehistory or to the recent/modern period.

\section{The outlook}

The systematic sampling at the Budmerice-Sušička site (if it continues) predetermines the retrieved material for more extensive archaeobotanical analysis. In this case it concerns a palaeoeconomic analysis and an analysis of weed ecology. The monograph by M. Hajnalová is an example of the currently most thorough archaeobotanical study in Slovak (2012). The author has focused on the archaeobotany of the Bronze Age and her methods and results serve as inspiration and are analogical to a considerable extent for the planned analyses from Budmerice.

The results of the archaeobotanical analysis will additionally be the subject of a synthesis with the results of the other analyses which have been introduced in this paper and which are an inseparable part of our systematic research. From the environmental point of view, the involvement of the above-mentioned analyses into our research represents an attempt to obtain a more complete picture concerning the life of the site inhabitants. By communicating the results of the archaeobotanical and palynological analysis, a contribution can be made to the reconstruction of the site environment. Moreover, for a more general view of the site, an analysis of the malacofauna from the excavated contexts is planned in the future.

The combination of the results of the archaeobotanical and archaeozoological analysis can contribute to a determination of the husbandry regime and the strategies at the site, as well as to the detection of the subsistence manner, based on the plant or animal resources (?) of the inhabitants. With the help of the analyses of the inorganic artefacts or their remains (such as the archaeometallurgical and petrographic analysis of the pottery, the petrological analysis of the stone industry, etc.) conclusions can be reached as to the extent of craft production activities and their position within husbandry, as well as in comparison with animal or plant husbandry. All the above-mentioned analyses can help solve the question of the general extent of husbandry at the site and the scale of production (small-scale economy, primarily for the local needs or a surplus).

The synthesis of all the presented results, along with the archaeological relative and absolute dating (dendrochronology, radiocarbon dating; Barta, Jelínek, Hlavatá, Vavák., in prep.), of our outputs will serve to elucidate the concept of basic life needs and of life in general of people at the time of the Mad'arovce culture.

Anthropological finds from the settlements often remain on the periphery of research interest. Using modern bioanalyses they can be a source of significant knowledge (cf. Salaš et al. 2012). The methods of archaeobotanical or environmental research serve to significantly improve the finding potential of the site. The method of extraction 
of plant remains by flotation can be a sound example for a situation when not only the archaeobotanical but also even minute archaeological artefacts are retrieved which, although not spotted by the archaeologist in the field, might have a decisive importance. When carrying out the archaeobotanical or environmental research, advantage can be taken of the analyses and results of other, chiefly natural scientific disciplines. They allow us to primarily learn more about the basic condition of human existence, i.e. about achieving subsistence, and consequently also about additional activities that can produce a more complete perspective of previous human life.

\section{References}

ACSÁDI, G., NEMESKÉRI, J. 1970: History of Human Life Span and Mortality. Budapest. Akadémiai Kiadó.

AMBROS, C. 1971: Ein Beitrag zur Frage der Anthropophagie in den Bronzezeitlichen Siedlungen in der Slowakei. Acta Facultatis Rerum naturalium Universitatis Comenianae / Anthropologia 17, 1-14.

BARTA, P., JELÍNEK, P., HLAVATÁ, J., VAVÁK, J.: Chronometric Dating of settlement features with human remains from hillfort of Mad'arovce culture in Budmerice, West Slovakia. Geochronometria, In preparation.

BARTÍK, J. 1993: Hromadný nález bronzov z Budmeríc - Jablonca. Zborník SNM 87, Arch. 3, 13-17.

BARTÍK, J., ŠTRBÍK, J. 1995: Prieskum v povodí malokarpatských potokov. Archeologické výskumy a nálezy na Slovensku 1994, 25.

BÁTORA, J. 1985: Prieskum zameraný na zistenie sídlisk zo začiatku doby bronzovej na juhozápadnom Slovensku. Archeologické výskumy a nálezy na Slovensku 1984, 42-45.

BÁTORA, J., MARKOVÁ, K. 1998: Z prieskumu Budmeríc a Jablonca, Archeologické výskumy a nálezy na Slovensku 1996, 27-28.

BERTOVÁ, L. (Ed.) 1982: Flóra Slovenska III. Veda Bratislava.

BERTOVÁ, L. (Ed.) 1984: Flóra Slovenska IV/1. Veda Bratislava.

BERTOVÁ, L. (Ed.) 1985: Flóra Slovenska IV/2. Veda Bratislava.

BERTOVÁ, L. (Ed.) 1992: Flóra Slovenska IV/3. Veda Bratislava.

BERTOVÁ, L., GOLIÁŠOVÁ, K. (Eds.) 1995: Flóra Slovenska V/1. Veda Bratislava.

BEUG, H. J. 2004: Leitfaden der Pollen bestimmung für Mitteleuropa und angrezende Gebiete. Verlag Dr. Friedrich Pfeil. München.

BUIKSTRA, J. E., UBELAKER, D. H. 1994: Standards for data collection from human skeletal remains. In: Proceedings of a Seminar at The Field Museum of Natural History organized by Jonathan Haas. Fayetteville, Arkansas Archeological Survey Research.

DAŇO, R. 2002: Pohrebný rítus únětickej kultúry na juhozápadnom Slovensku. MS. Master diploma thesis. Deposited: Archeological Institute of Slovak Academy of Science, Nitra.

DAŇOVÁ, K. 2010: Sociálne postavenie detí od neolitu po koniec staršej doby bronzovej v severnej časti Karpatskej kotliny. MS. Master diploma thesis. Deposited: Archeological Institute of Slovak Academy of Science, Nitra.

ELIADE, M. 2004: Pojednáni o dějinách náboženství. First ed. Argo Logos, Praha.

ERNÉE, M 2000: Hroby únětické kultury z Prahy 9 - Miškovic (Př́spěvek $\mathrm{k}$ diskusi o smysluplnosti zkoumání „dalších“ únětických hrobů). In: Čech, P., Dobeš, M. (Eds.): Sborník Miroslavu Buchvaldkovi. Most, 71-76.

FAEGRI, K., IVERSEN, J. 1989: Textbook of pollen analysis. Fourth ed. John Wiley \& Sons, Chichester.

FARKAŠ, Z. et al. 1980: Nové nálezy z Budmeríc. Archeologické. rozhledy 32, 491-500.

FEREMBACH, D., SCHWIDETZKY, I., STLOUKAL, M. 1970: Empfehlungen für die Alters- und Geschlechtsdiagnose am Skelett. HOMO 30(1), 1-32.

FODOR, R. 1997: Osídlenie údolia potoka Gidra vo vzt’ahu k prírodným pomerom. MS. Master diploma thesis. Deposited: Department of
Archaeology Faculty of Arts, University of Constantine the Philosopher, Nitra.

FURMÁNEK, V., JAKAB, J. 1997: Menschliche Skelettreste aus bronzezeitlichen Siedlungen in der Slowakei. In: Rittershofer, K - F. (Ed.): Sonderbestattungen in der Bronzezeit im östlichen Mitteleuropa. Internat. Arch. 37. Espelkamp, 14-23.

FUTÁK, J. (Ed.) 1966: Flóra Slovenska II. Bratislava.

GAILLARD, M. J. 2007: Detecting of human impact in the pollen records. In: Elias, S. A. (Ed.) Encyclopedia of Quaternary Science. University of London, Elsevier, 2570-2595.

GOLIÁŠOVÁ, K. (Ed.) 1998: Flóra Slovenska V/2. Veda Bratislava.

GOLIÁŠOVÁ, K., MICHÁLKOVÁ, E. (Eds.) 2006. Flóra Slovenska V/3. Veda Bratislava.

GOLIÁŠOVÁ, K., ŠÍPOŠOVÁ, H. (Eds.) 2002: Flóra Slovenska V/5. Veda Bratislava.

GOLIÁŠOVÁ, K., ŠÍPOŠOVÁ, H. (Eds.) 2008: Flóra Slovenska VI/1. Flóra Slovenska.

HAJNALOVÁ, E. 1990: Antrakotomické rozbory z archeologických výskumov na Trnavskej pahorkatine a v údolí Váhu. Študijné. Zvesti AÚ SAV 26, 223-236.

HAJNALOVÁ, E. 1993: Obilie v archeobotanických nálezoch na Slovensku. Acta interdisciplinaria Archeologica 8, Nitra.

HAJNALOVÁ, M. 2012: Archeobotanika doby bronzovej na Slovensku. Śtúdie ku klíme, prírodnému prostrediu, polnohospodárstvu a paleoekonómii. Univerzita Konštantína Filozofa v Nitre, Nitra.

HAJNALOVÁ, M., HAJNALOVÁ, E. 1998: Preplavovanie - metóda získavania rastlinných makrozvyškov z archeologických objektov a vrstiev. (Water Flotation - method for the recovery of plant macroremains from archaeological features and layers.) Informátor SAS pri SAV 8/1, 6-7.

HAJNALOVÁ, M., VARSÍK, V. 2010: Kvádske rolníctvo na Slovensku z pohl'adu archeológie a archeobotaniky. In: Beljak, J., Březinová, G., Varsík, V. (Eds.): Archeológia Barbarov 2009. Hospodárstvo Germánov. Sídliskové a ekonomické štruktúry od neskorej doby laténskej po včasný stredovek. Nitra, 181-224.

HANIHARA, K., SUZUKI, T. 1978: Estimation of Age from the Pubic Symphysis by Means of Multiple Regresion Analysis. American Journal of Physical Anthropology 48(2), 233-240.

HANZELYOVÁ, E. et al. 1995: Letecká prospekcia na juhozápadnom Slovensku, Archeologické výskumy a nálezy na Slovensku 1993, 54-55.

HERMANN, B., GRUPE, G., HUMMEL, S., PIEPERBRINK, H., SCHUTKOWSKI, H. 1990: Prähistorische Anthropologie. Leitfaden der Feld- und Labormethoden. Berlin, New York, Springer-Verlag.

IŞCAN, M. Y., DERRICK, K. 1984: Determination of Sex from the Sacroiliac. A Visual Assessment Technique. Florida Scientist 47, 94-98.

JACOMET, S., KREUTZ, A. 1999: Archaobotanik. Verlag Eugen Ulmer, Stuttgart.

JAKAB, J. 2007: Grundkennziffern der Paläodemographie der frühbronzezeitlicher Gräberfelder von Jelšovce, Slovenská Archeológia 55/2, 277-283.

JELÍNEK, P. 2009: Nálezy skeletov v sídliskových objektoch - ich interpretácia a význam. MS. Master diploma thesis. Deposited: Department of Archaeology Faculty of Arts, University of Constantine the Philosopher, Nitra.

JELÍNEK, P. in press: Contribution article on spiritual life in the mad'arovce culture. In: Archeology at Three Continents 2006-2011. Slovak Archeological and Historical Institute (in print).

JELÍNEK, P., VAVÁK, J. in press: Human remains in settlements pits of the mad'arovce culture in Slovakia (Early bronze age). In: Müller-Scheeßel, N. (Ed.): Irreglärre' Bestattungen in der Urgeschichte: Norm, Ritual, Strafe... Internationale Tagung, Frakfurt am Main, 3.-5. Februar 2012, , Frankfurt am Main (in print).

JELÍNEK, P. et al. 2011: Systematický výskum opevnenej osady mad'arovskej kultúry $\mathrm{v}$ Budmericiach (okr. Pezinok). Informátor Slovenskej archeologickej spoločnosti 22/2, 1-3.

JONES, M. K. 1991: Sampling in palaeoethnobotany. In: van Zeist, W., Wasylikowa, K., Behre, K.-E. (Eds.): Progress in Old World Palaeoethnobotany. Rotterdam, 53-62.

KNUSSMANN, R., SCHWIDETZKY, I., JÜRGENS, H. W., ZIEGELMAYER, G., 1988: Anthropologie. Band I. Wesen und Methoden der Anthropologie. Stuttgart, Gustav Fischer Verlag. 
KOVÁRNÍK, J. 2010: Proč jsou hroby také na sídlištích z neolitu a eneolitu? In: Tichý, R., Štulc, O. (Eds.): Živá archeologie-Supplementum 3. Hroby, pohřby a lidské pozůstatky na pravěkých a středověkých sídlištich. Hradec Králové, 50-57.

KRASŇANOVÁ, M. 1994: Kontinuita osídlenia lokality Jablonca od najstarších čias po ranný stredovek. MS. Master diploma thesis. Deposited: Department of Archaeology Faculty of Arts, University of Constantine the Philosopher, Nitra.

KRIPPEL, E. 1986: Postglaciálny vývoj vegetácie Slovenska. Bratislava.

KUZMA, I. 2002: Výskum na trase optického kábla Budmerice - Jablonec. Archeologické výskumy a nálezy na Slovensku 2001. Nitra, 96-98.

KUZMA, I., BARTÍK, J. 2009: Letecká prospekcia na juhozápadnom Slovensku. Archeologické výskumy a nálezy na Slovensku 2007, 124-128.

LITYŃSKA-ZAJAC, M., WASYLIKOWA, K. 2005: Przewodnik do Badań archeobotanicznych. Poznań.

LOVEJOY, C. O. 1985: Dental Wear in the Libben Population. Its Pattern and Role in the Determination of Adult Skeletal Age at Death. American Journal of Physical Anthropology 68(1), 47-56.

LOVEJOY, C. O., MEINDL, R. S., PRZYBECK, T. R. 1985: Chronological Metamorphosis of the Auricular Surface of Illium. A New Method for the Determination of Adult Skeletal Age at Death. American Journal of Physical Anthropology 68(1), 15-28.

MAGYARI, E. K., CHAPMAN, J. C., PASSMORE, D. G., ALLEN, J. R. M., HUNTLEY, J. P., HUNTLEY, B. 2010: Holocene persistence of wooden steppe in Great Hungarian Plain. Journal of Biogeography 37, 915-935.

MEINDL, R. S., LOVEJOY, C. O. 1985: Ectocranial Suture Closure: A Revised Method for the Determination of Skeletal Age at Death and Blind Tests of its Accuracy. American Journal of Physical Anthropology 68 (1), 57-66.

NESBITT, M. 1995: Recovery of archaeological plant remains at KamanKalehöyük. In: Mikasa, T. (Ed.): Essays on ancient Anatolia and its surrounding civilizations, vol. 8, Bulletin of the Middle East Culture Centre in Japan. Harrassowitz, Wiesbaden, 115-130.

NOVOTNÝ, B., FUHRHERR, V 1971: Katalóg archeologickej zbierky Západoslovenského múzea v Trnave. Bratislava.

OŽDÁNI, O. 1998: Einige anmerkungen zum Vorkommen der „Litzen“Verzierungim Milieu der Otomani-kultur und ihr chronologischer Aspekt. Východoslovenský Pravek 5, 51-57.

PALÁTOVÁ, H., SALAŠ M. 2002: Depoty keramických nádob doby bronzov na Moravě a v sousednich zemich. Pravěk Supplementum 9. Brno.

PAVÚK, J., BÁTORA, J. 1995: Siedlung und Gräber der Ludanice-Gruppe in Jelšovce. Nitra.

PEARSALL, D. M. 2000: Palaeoethnobotany: a Handbook of Procedures. Academic Press, San Diego.

PHENICE, T. W. 1969: A Newly Developed Visual of Sexing the Os Pubis American Journal of Physical Anthropology 30(2), 297-301.
PICHLEROVÁ, M. 1971: Nové nálezy mad’arovskej kultúry v Zbierkach SNM v Bratislave. Zbornik Slovenského Národného Múzea 55. História11, 5-23.

PRENTICE, C. 1985: Pollen representations, source area, and basin size: Towards a unified theory of pollen analysis. Quaternary Research 23, 76-86.

REILlE, M. 1992: Pollen et spores D'Europe et D'Afrique du Nort. Laboratoire de botanique historique et palynologie, Marseille.

REILLE, M. 1995: Pollen et spores D'Europe et D'Afrique du Nort. Supplement 1. Laboratoire de botanique historique et palynologie, Marseille.

REILLE, M. 1998: Pollen et spores D'Europe et D'Afrique du Nort. Supplement 2. Laboratoire de botanique historique et palynologie, Marseille.

SALAŠ, M. 1990: Únětická sídlištní jáma s lidskými kosterními pozůstatky na Cezavách u Blučiny. Památky archeologické 81, 275 - 307.

SALAŠ, M. et al. 2012: Potravní zdroje obyvatelstva mladší doby bronzové na Cezavách u Blučiny: analýzy bioarcheologických pramenů. Archeologické rozhledy 64, 391-442.

SCHVARCOVÁ, Z. 2009: Opevnené osady mad’arovskej a otomanskej kultúry na Slovensku. Príspevok k sídliskovej štruktúre v staršej dobe bronzovej. MS. Master diploma thesis. Deposited: Department of Archaeology Faculty of Arts, University of Komenský, Bratislava.

SJøVOLD, T. 1990: Estimation of Stature from Long Bones Utilizing the Line of Organic Correlation. Human Evolution 5(5), 431-447.

SUGITA, S. 1994: Pollen representation of vegetation in Quaternary sediments - theory and method in patchy vegetation. Journal of Ecology 82, 881-897.

SUGITA, S, GAILlARD, M. J., BROSTRÖM, A. 1999: Landscape openness and pollen records: a simulation approach. The Holocene 9, 409-421.

SVENNING, J. CH. 2002: A review of natural vegetation openness in north-western Europe. Biological Conservation 104, 133-148.

TIRPÁK, J. 2008: Geofyzikálny prieskum Budmerice, poloha Farárova rola. MS. Excavation report. Deposited: Malokarpatské muzeum v Pezinku, Pezinok.

TOČÍ́K, A. 1962: Nález mad’arovskej keramiky v Budmericiach. Študijné Zvesti AÚ SAV 9, 81-97.

UBELAKER, D. H. 1987: Estimating Age at Death from Immature Human Skeletons: An Overview. Journal of Forensic Sciences 32(5), 1254 1263.

VAVÁK, J. 2004: Západná skupina mad’arovskej kultúry. MS. Master diploma thesis. Deposited: Department of Archaeology Faculty of Arts, University of Constantine the Philosopher, Nitra.

VAVÁK, J. 2007: K osídleniu mad’arovskej kultúry medzi Moravou a Váhom. MS. Master diploma thesis. Deposited: Department of Archaeology Faculty of Arts, University of Constantine the Philosopher, Nitra. 
